Dr. sc. VLADIMIR HUZJAN, viši znanstveni suradnik Zavod za znanstveni rad Hrvatske akademije znanosti i umjetnosti u Varaždinu Varaždin, Republika Hrvatska vhuzjan@gmail.com UDK 94:355.11(=163.41)(497.5)"1918/1941"(093.2)

prethodno saopštenje / preliminary communication primljeno / received: 4. 2. 2020.

prihvaćeno / accepted: 20. 5. 2020.

https://doi.org/10.29362/ist20veka.2020.2.huz.61-84

\title{
O POKOPANIM VOJNICIMA SRPSKE NACIONALNOSTI NA VARAŽDINSKOM GROBLJU IZMEĐU DVA SVJETSKA RATA
}

APSTRAKT: $U$ radu autor piše o pokopanim vojnicima srpske nacionalnosti na varaždinskom groblju između Prvog i Drugog svjetskog rata. Od ukupnog broja pokopanih vojnika srpske nacionalnosti gotovo svi su bili vojnici Kraljevine SHS/Jugoslavije. Podaci su preuzeti iz knjiga Grobni očevidnik (1919.-1939.) i Grobni očevidnik (1940.-1949.) koje čuva gradska komunalna tvrtka Parkovi d. d. Za svakog pojedinog vojnika poznat je identitet, a popis se nalazi u prilogu. ${ }^{1}$

KLJUČNE RIJEČI: Varaždin, vojska, srpski vojnici, groblje, bolest, smrt, Jugoslavija, Kraljevina SHS

\section{Uvod}

Danas se relativno malo zna o povijesti srpske zajednice u Varaždinu jer lokalna historiografija nije istraživala njihov politički, kulturni i društveni utjecaj na grad i okolicu. Do druge polovice 19. stoljeća Srbi su u Varaždinu najčešće (privremeno) boravili kao putujući trgovci, činovnici ili vojnici, a obitelji su bile tek rijetko trajno nastanjene. Za prvu polovicu 19. stoljeća Stjepan Krivošić navodi podatke o naseljenosti Srba, ali zbirno i to za mjesta Bolfan i Ćukovec (udaljena od Varaždina oko 35 kilometara) i Torčec (udaljen od Varaždina oko 50 kilometara). U tim mjestima je 1802. živjelo 164, a 1857. godine $393 \mathrm{Srba}^{2}$ Prema popisu stanovništva iz 1880. na području Varaždinske župani-

\footnotetext{
${ }^{1}$ Podaci o svim pokopanim vojnicima na varaždinskom groblju između dva svjetska rata objavljeni su u: Vladimir Huzjan, Varaždin i vojska u međuratnom razdoblju (1918.-1941.) (ZagrebVaraždin: Hrvatska akademija znanosti i umjetnosti, Zavod za znanstveni rad u Varaždinu, 2017), 285-308. Za potrebe ovog rada, dio koji se odnosi na pokopane vojnike srpske nacionalnosti dodatno je historiografski istražen i analiziran.

${ }^{2}$ Stjepan Krivošić, Stanovništvo i demografske prilike u sjeverozapadnoj Hrvatskoj u 18. i prvoj polovini 19. stoljeća (Zagreb-Varaždin: Hrvatska akademija znanosti i umjetnosti, Zavod za znanstveni rad u Varaždinu, 1991), 103.
} 
je živjelo je 1.888 stanovnika pravoslavne vjeroispovijesti ili 0,8 posto ukupnog stanovništva. ${ }^{3}$ Srpska zajednica u Varaždinu organizirana je tek 5. prosinca 1882. osnutkom Crkvene općine, a na poticaj varaždinskog velikog župana Ognjeslava Utješenovića Ostrožinskog. Dva dana kasnije tadašnji gradski načelnik Milan Vrabčević odobrio je da se dvije sobe gradskog kazališta koriste kao kapela. Specifična okolnost je da su obojica bili istaknuti pripadnici pravoslavne zajednice u Hrvatskoj.

Kako je s vremenom rasla potreba, Grad Varaždin je ubrzo darovao zemljište na današnjem Trgu bana Jelačića za gradnju prve pravoslavne kapele u gradu. Gradnja je išla brzo - 28. lipnja 1884. stavljen je kamen temeljac, 12. listopada posvećena su nova zvona, a 2 . studenoga blagoslovljena je kapela. ${ }^{4}$ Dakle, svega dvije godine od osnutka Crkvene općine. Po završetku izgradnje krajem 19. stoljeća, varaždinska kapela sv. Đorđa (Jurja) bila je tada posljednja pravoslavna kapela izgrađena u središtu nekog grada Banske Hrvatske. ${ }^{5}$ Što se tiče upravne organizacije, varaždinska kapela spadala je pod parohiju u Bolfanu. Kada će se 1892. u Varaždinu osnovati Srpska pravoslavna parohija, kapela sv. Đorđa postat će parohijska crkva. ${ }^{6}$

Kako se u ovom radu govori o vojnicima srpske nacionalnosti pokopanim na varaždinskom groblju između dva svjetska rata, treba napomenuti da se oni ne smatraju dijelom varaždinske srpske zajednice (poput svećenika, nastavnika, trgovaca i sl.) jer nisu trajno boravili u gradu već privremeno dok je trajao vojni rok.

\section{Varaždin između dva svjetska rata}

Završetak Velikog rata i raspad Austro-Ugarske Monarhije u Varaždinu je dočekan radosno - građani su klicali kralju Petru I. Karađorđeviću, Woodrovu Wilsonu te vrijeđali cara Karla i cara Vilhelma II. ${ }^{7}$ Sve što je podsjećalo na bivšu monarhiju je uklonjeno. Prije završetka Velikog rata osnovan je lokalni odbor Narodnog vijeća Slovenaca, Hrvata i Srba koji je osnovao lokalne odjele Narodne vojske. Ona je u gradu razoružala sve strane vojnike i oslobodila srpske ratne zarobljenike, no nema podataka o kolikom se broju zarobljenika radilo. Do 5. studenoga 1918. u Varaždin je stigao prvi izvidnički odred srpske ko-

\footnotetext{
${ }^{3}$ „Rezultati popisa žiteljstva (...)“, Varaždinski viestnik, 7. veljače 1891., 2.

${ }^{4}$ Arhiv Srpske pravoslavne crkvene općine Varaždin (ASPCOV), Odbor pravoslavne srbske crkvene općine varaždinske, 9./21. studenoga 1883.

${ }^{5}$ Lazar Bogdanović, Srpska pravoslavna crkva sv. Đurđa u Varaždinu (Sremski Karlovci: Srpska manastirska štamparija, 1897); Jovan Nikolić, Aktivnost Utješenovića u životu pravoslavne parohije i crkvene opštine u Varaždinu s posebnim osvrtom na gradnju hrama sv. Đurđa (Zagreb, 1990); Dragan Damjanović, „Gradnja i opremanje varaždinske pravoslavne crkve 1884. godine", Radovi Zavoda za znanstveni rad Varaždin, 24, (2013), 317-340; Hrvoje Petrić i Filip Škiljan, Iz povijesti Srba u Varaždinskoj županiji od prvih doseljavanja do današnjih dana (Zagreb: Grafocentar, 2017), i dr.

${ }^{6}$ U vrijeme pisanja ovog rada đakon Srpske pravoslavne crkve u Varaždinu je Uglješa Pilinger, a kulturno je aktivna i Srpska nacionalna manjina grada Varaždina.

${ }^{7}$ Vladimir Huzjan, „Varaždin u vrijeme Države Slovenaca, Hrvata i Srba - od 29. listopada do 1. prosinca 1918. godine“, Radovi Zavoda za znanstveni rad Varaždin, 22, (2011), 249-281.
} 
njice pod zapovjedništvom natporučnika Vlaisavljevića. ${ }^{8}$ Nedugo zatim, vijest o stvaranju Kraljevstva SHS također je dočekana radosno. Zabilježeno je sljedeće: „Vijest o proglašenju ujedinjenja kraljevine Srbije sa Hrvatskom i Slovenijom u zajedničku kraljevinu Srba, Hrvata i Slovenaca stigla je u Varaždin na odbor Narodnoga Vijeća u ponedjeljak u 9 sati na veče. Kako je u to vrijeme bilo gradjanstvo u pozorištu, to je ravnatelj g. Mitrović sa pozornice pročitao radosne vijesti o narodnom našem ujedinjenju i proglašenju kralja Petra za vladara Srba, Hrvata i Slovenaca. Općinstvo je na to ustalo sa sjedala i oduševljeno udarilo u pljesak i klicanje. Iz loža i partera orilo se: Živio kralj Petar prvi, kralj svih Jugoslavena, živio kraljević Aleksandar, živila kraljevina Srba, Hrvata i Slovenaca. Na to je glazba zaigrala hrvatsku himnu Lijepu našu domovinu i srpsku himnu Bože pravde $(. . .)^{\text {“‘ }}$ ?

Novo državno i političko okruženje trebalo je objasniti i ljudima izvan grada. Tako je Sekcija za organizaciju i agitaciju Narodnog vijeća SHS donijela uputu kojom se stanovništvu objašnjava da je dinastija Karađorđevića narodna, kralj Petar prijatelj Hrvatima, a njegov sin Aleksandar bolji hrvatski domoljub od bilo kojeg lokalnog republikanca. ${ }^{10}$ Seljaci su tražili: „Da Narodno vijeće dade narodu najprije kruha (...) pa će tada narod biti za dinastiju Karagjorgjevića“. ${ }^{11}$ Unatoč političkoj promidžbi nove vlasti, u Varaždinu su se 23. srpnja 1919. oružano pobunili hrvatski vojnici Savske konjičke pukovnije (puka) i neki građani tražeći osnivanje republike. Vojska je ugušila jednodnevnu bunu, prijeteći da će topovima bombardirati grad, u kojoj su među pobunjenicima bila ranjena četvorica i jedan poginuo, a među srpskim vojnicima trojica su bila ranjena, a dvojica poginula (jedan kasnije i pokopan na gradskom groblju). ${ }^{12}$ Tako se vojska prikazivala kao osloboditeljica, no braneći rigidni politički sustav često je doživljavana kao okupator. U Varaždinu i u Međimurju bilo je slučajeva zlostavljanja stanovništva. ${ }^{13}$

Do sredine 1920-ih političko stanje u gradu je bilo toliko turbulentno da je vlast preuzeo privremeni upravitelj. U takvom okruženju grad je nakratko posjetio kralj Aleksandar. Prvi puta u lipnju 1924. godine. Iako je načelno sve prošlo dobro, lokalnog zlatara Franju Brombaurea pretukli su članovi ORJUNA-e jer nije izvjesio državnu zastavu. ${ }^{14}$ Drugi puta kralj Aleksandar posjetio je Varaždin u listopadu 1925. kada je bio na proputovanju do nedalekog imanja Opeka u vlasništvu grofova Bombelles.

Na izborima 1928. pobijedila je lista Samostalne demokratske stranke i izabrala Hinka Krizmana za gradskog načelnika. No, nakon atentata i ubojstva

\footnotetext{
${ }^{8}$ Više o Varaždinu u međuratnom razdoblju vidi u: V. Huzjan, Varaždin i vojska u međuratnom razdoblju (1918.-1941.).

9 „Dojam u Varaždinu“, Volja naroda, 5. prosinca 1918., 2.

${ }^{10}$ Arhiv Jugoslavije, zbirka 84, Hinko Krizman (AJ, HK), Ostali materijali, br. 785-1918.

${ }^{11}$ Isto, zapisnik sjednice od 8. prosinca 1918.

12 Više vidi u: Mile Bjelajac, Vojska Kraljevine Srba, Hrvata i Slovenaca 1918-1921 (Beograd: Narodna knjiga, Institut za istoriju radničkog pokreta Srbije, 1988), 135, 240.

13 „U spomenar g. Rojcu i Novoj Evropi“, Slobodni gradjanin, 23. travnja 1921., 1-2.

14 „The wild west (divlji zapad)“, Hrvatsko jedinstvo, 14. lipnja 1924., 2.
} 
hrvatskih zastupnika u Narodnoj skupštini u Beogradu, a posebno nakon smrti Stjepana Radića, u Varaždinu su održani protesti. Policijski agenti zabilježili su neke od izjava poput da je to: ,(...) jedan dobro spremljeni i promišljeni čin beogradske čaršijske i srbijanske korumpirane pljačkaške klike, koja već 10 godina harači i pljačka u ime nekolicine $(. . .)^{\text {“ }}$. $^{15}$

Kralj Aleksandar posjetio je treći i posljednji put Varaždin u ljeto 1931. godine. Doček je bio pomno organiziran uz propagandnu najavu u lokalnim medijima: „(...) mi ćemo (...) opravdati mišljenje cijelog Beograda, a i zvaničnih krugova. Ako upitate koji je grad u našoj zemlji najviše zadojen jugoslavenskom idejom - onda na svakom mjestu (...) vam bez razmišljanja odgovara(ju): Varaždin. Jeste. Varaždin je to bio, to je sada, to će i ostati“. ${ }^{16}$

S druge strane, jedan od sudionika tih događaja izjavio je kako su po naređenju bana iz svakog sela morala doći odjevena u seljačka odjela dva odbornika, gradski službenici i radnici, kao i školska djeca. ${ }^{17}$

$\mathrm{U}$ to vrijeme u Varaždinu je živio i pješadijski brigadni general Panta Draškić kao zapovjednik Savske pješadijske brigade. ${ }^{18}$ Aktivno je sudjelovao u društvenom životu grada: obilježavao je obljetnicu sloma Solunskog fronta, novčano pomagao crkvu i dobrotvorna društva, slavio Dan ujedinjenja, kraljev rođendan $\mathrm{i} \mathrm{dr}$.

Unatoč političkoj represiji i javnoj propagandi, pojavljivali su se primjeri antidržavnog djelovanja. Po svom sadržaju izdvajaju se dva primjera: u obližnjem mjestu Sračinec pri posveti vatrogasnog doma zapovjednik vatrogasne župe Varaždin Antun Lazar zaustavio je orkestar dok je svirao državnu himnu i inzistirao da sviraju hrvatsku ili kada je netko u ožujku 1932. u zgradi gimnazije stavio na pod sliku kraljevske obitelji i na njoj obavio veliku nuždu. ${ }^{19}$

Tijekom 1930.-ih na čelu grada izmijenilo se više gradskih načelnika, a najveći trag ostavio je Stjepan Novaković koji je bio predsjednik ogranka Jugoslavenske nacionalne seljačke demokracije, a u njegovo vrijeme djelovao je $\mathrm{i}$ lokalni ogranak Udruženja četnika za slobodu i čast otadžbine koji je na prijedlog lokalnih vlasti ukinut 1936. sa sljedećim objašnjenjem: „(..) samo postojanje udruženja stvaralo je od prvog dana njihovog postojanja zlu krv među građanima. Građani ih mrze, jer ih smatraju za uzročnike svega što nije dobro i za velike neprijatelje hrvatstva. (...) Premda su četnici mirni i izbegavaju sve što bi moglo dati povoda za sukobe i fizička obračunavanja, ipak je na strani hrvatskih

${ }^{15}$ Državni arhiv u Varaždinu, Gradsko poglavarstvo Varaždin, Prezidijani spisi 1928.-1932. (HRDAVŽ, GPV PS), kut. br. 20., god. 1928., br. 8.

${ }^{16}$ „Dolazak Nj. V. Kralja u Varaždin. Dobro nam došao!“, Varaždinske novosti, 4. lipnja 1931., 1. Boravak kralja Aleksandra u sjevernoj Hrvatskoj detaljnije je opisan u propagandnoj monografiji: Kralj i narod. Trijumfalna putovanja Njegova Veličanstva Kralja po Savskoj banovini 1. VI.-18. VI. 1931., ur. Petar Mihočević (Zagreb, 1931).

17 „Vidjevši neuspjeh - kralj je odmaglio“, Varaždinske vijesti, 19. studenoga 1981., 2.

${ }^{18}$ Vladimir Huzjan, „Život generala Kraljevine Jugoslavije u Hrvatskoj - Panta Draškić u Varaždinu“, Historia Varasdiensis. Časopis za varaždinsku povjesnicu, 2, (2012), 175-184.

${ }^{19}$ Hrvatski državni arhiv, Okružni inspektorat Varaždin, Povjerljivi spisi 1932. (HR-HDA, OIV PS). Na dokumentu je oznaka: 32(?)/1932. 
separatista i omladinaca takovo raspoloženje, da može svaki čas doći do napadaja na četnike $(. . .)^{\text {“ }}$. $^{20}$

Nakon atentata na kralja Aleksandra, S. Novaković osnovao je Odbor za podignuće spomenika Viteškom Kralju Aleksandru I. Ujedinitelju u gradu Varaždinu. ${ }^{21}$ Spomenik Antuna Augustinčića podignut je 1935. ispred gradske vijećnice na rođendan kralja Petra II. Bio je visok 6,5 metara (s postamentom) i vjerojatno jedini u Hrvatskoj koji je kralja Aleksandra prikazao u figuri. Spomenik je srušen dan nakon proglašenja Nezavisne Države Hrvatske. ${ }^{22}$

U zaključku o međuratnom Varaždinu treba reći da je ukinućem Varaždinske županije i seljenjem ravnateljstva financija, grad počeo gubiti na važnosti i gospodarski siromašiti. Agrarnom reformom izgubio je najveći dio zemljišta, a time i prihoda gradskoj blagajni. Drugi važan dio prihoda bio je najam vojarni. Dok je austro-ugarska vojska plaćala u zlatnim krunama, jugoslavenska je plaćala manje u dinarima i to neredovito, a od 1935. uopće nije plaćala. Time je Grad Varaždin u međuratnom razdoblju bio ozbiljno zakinut za znatan dio svojih prihoda. $^{23}$ Što se tiče Srba u Varaždinu, prema popisu stanovništva iz 1931., u gradu i okolici živjelo je 705 stanovnika pravoslavne vjere. Do početka Drugog svjetskog rata bili su aktivan dio zajednice, no s uspostavom NDH pokrenut je postupak njihove diskriminacije, progona i uhićenja s tragičnim posljedicama. ${ }^{24}$

\section{Analiza podataka iz grobnih očevidnika}

Uspostavom novog kraljevstva stvorena je i nova vojno-teritorijalna podjela. Varaždin je spadao u IV. vojnu (armijsku) oblast koja se sastojala od Dravske, Savske i Osiječke divizijske oblasti. Savska divizijska oblast imala je sjedište u Zagrebu i bila je podijeljena na tri vojna okruga: karlovački, varaždinski i za-

${ }^{20}$ Fikreta Jelić-Butić, „Iz povijesti četničkog pokreta u Hrvatskoj između dva rata (1934.-1936.). Prilog građi o četničkim udruženjima u Savskoj banovini 1934.-1936.“, Radovi Zavoda za hrvatsku povijest Filozofskog fakulteta, vol. 21, (1988.), 209.

21 Vladimir Huzjan, „O primjerima projugoslavenski orijentirane varaždinske gradske uprave prema kralju Aleksandru I. Karađorđeviću“, Radovi Zavoda za znanstveni rad Varaždin, 21, (2010), 219-252.

22 Vladimir Huzjan, „Varaždin u zadnjim mjesecima Kraljevine Jugoslavije i prvim Nezavisne Države Hrvatske“, Radovi Zavoda za znanstveni rad Varaždin, 23, (2012), 363-400.

${ }^{23}$ Vladimir Huzjan, "Expropriation of feudal property in the interwar period - examples of free and royal town of Varaždin and Stari grad seniorate possession belonging to counts of Erdödy", Review of Croatian History, XV, 1, (2019), 151-164; V. Huzjan, Varaždin i vojska u međuratnom razdoblju (1918.-1941.), 218.

${ }^{24}$ Više o stradanju Srba u vrijeme NDH na području sjeverozapadne Hrvatske vidi u: Marica Karakaš Obradov, „Migracije srpskog stanovništva na području Nezavisne Države Hrvatske tijekom 1941. godine“", Časopis za suvremenu povijest, 3, (2011), 801-826; Filip Škiljan, Organizirana prisilna iseljavanja Srba iz NDH (Zagreb: Srpsko narodno vijeće, 2014); Vladimir Šadek, ,Postupanje ustaškog režima s imovinom Židova i Srba u kotarima Koprivnica i Đurđevac (1941.-1942.)“", Podravina: časopis za multidisciplinarna istraživanja, 28, (2015), 5-16; Hrvoje Petrić, „Iz najstarije povijesti Srba u Podravini“, Podravina: časopis za multidisciplinarna istraživanja, 30, (2016), 199-212; H. Petrić i F. Škiljan, Iz povijesti Srba u Varaždinskoj županiji od prvih doseljavanja do današnjih dana (Zagreb: Grafocentar, 2017). 
grebački. U svom sastavu imala je 35. zagrebačku, 36. varaždinsku i 53. karlovačku pješadijsku pukovniju zajedno s 14. varaždinskom i 30. zagrebačkom topničkom pukovnijom. Sve dotadašnje pukovnije hrvatsko-ugarskog domobranstva su raspuštene, a odabrani vojnici uključeni su u novi vojni sustav Kraljevstva SHS. ${ }^{25}$ U novoj vojsci bilo je teško nastaviti karijeru - neki nisu uspjeli jer nisu znali pobrojati kote od Rijeke do Ljubljane ili pobrojati sve pritoke Drave od Maribora do Osijeka. ${ }^{26} \mathrm{U}$ lokalnom tisku zabilježen je sljedeći urednički komentar: „,...) naša država je umirovila gotovo sve oficire Hrvate, koji su služili u bivšoj austrougarskoj vojsci, kao da su oni krivi ratu sa Srbijom“. ${ }^{27}$

Varaždin je imao više vojnih objekata izgrađenih krajem 19. stoljeća. S uspostavom nove države nastala su i nova imena: Kraljevska ugarska domobranska pješačka vojarna promijenila je naziv u Kasarna kralja Petra I. Oslobodioca, zatim Ulanska vojarna u Konjaničku kasarnu, a od 1925. u Kasarnu vojvode Mišića. Topnička vojarna promijenila je ime u Kasarna kralja Aleksandra I. Ujedinitelja, a Komanda Varaždinskog vojnog okruga u Kasarnu vojvode Putnika itd. Upravo u tim vojnim objektima služili su vojnici vojske Kraljevine SHS/ Jugoslavije.

U promatranom razdoblju između Prvog i početka Drugog svjetskog rata sve osobe pokopane na varaždinskom groblju upisane su u knjigu Grobni očevidnik. Osobne podatke o njima upisivao je gradski činovnik: ime, prezime i zanimanje pokojnika, njegovu dob, bračno stanje i mjesto rođenja, zatim mjesto gdje je pokojnik boravio prije smrti, od čega je umro, datum i mjesto pokopa te po potrebi napomena. Za ovu temu obrađeni su podaci iz dviju knjiga: Grobni očevidnik (1919.-1939.) i Grobni očevidnik (1940.-1949.) koje u vrijeme pisanja ovog rada čuva gradska komunalna tvrtka Parkovi d. d.

Na gradskom groblju u Varaždinu organizirani pokop vojnika započeo je $\mathrm{u}$ vrijeme Velikog rata i nastavljen je u međuratnom razdoblju. ${ }^{28} \mathrm{U}$ promatrano vrijeme pokopano je ukupno 208 vojnika od kojih su neki bili umirovljenici bivše Austro-ugarske vojske. Od ukupnog broja, 82 ili 39,4 posto vojnici su srpske nacionalnosti. ${ }^{29}$ Među njima njih 51, ili 62 posto, bili su vojnici, regruti ili redovi. Od podoficira/dočasnika bio je samo kaplar Milan Jeremić iz Lugavčine, a od oficira/časnika pukovnik Stevan Lapčević iz Gline. ${ }^{30}$ On je sigurno bio časnik Austrougarske vojske i kao vojnik srpske nacionalnosti, koji je preminuo i bio pokopan na varaždinskom groblju u promatranom razdoblju, uvršten je na popis. No, za

${ }^{25}$ Više vidi u: Vladimir Huzjan, „Raspuštanje Hrvatskog domobranstva nakon završetka Prvog svjetskog rata“, Časopis za suvremenu povijest, 37, (2005), 445-465.

26 „Naša vojska i podoficiri Hrvati“, Narodno jedinstvo, 1. srpnja 1922., 3.

27 „Radić kao ministar i državna štednja“, Narodno jedinstvo, 4. veljače 1926., 3.

28 Vojnici žrtve Velikog rata pokopane su u III. polju varaždinskog groblja, vojnici Kraljevine SHS/Jugoslavije od I. do VIII. polja (najviše u III. i VIII.), a za vrijeme Drugog svjetskog rata njemački i talijanski vojnici te pripadnici ustaške vojnice i hrvatskog domobranstva najviše u VIII. Polju.

${ }^{29} \mathrm{U}$ međuratnom razdoblju na varaždinskom groblju pokopani su vojnici rođeni na području današnje Hrvatske, Slovenije, Bosne i Hercegovine, Sjeverne Makedonije, Rusije itd. Više vidi u: Vladimir Huzjan, Varaždin i vojska u međuratnom razdoblju (1918.-1941.), 201-210.

${ }^{30} \mathrm{U}$ Tablici 1 vidi red. br. 67, 10. 
njega nije utvrđeno je li aktivno služio u vojsci Kraljevine SHS/Jugoslavije. Za 36 posto vojnika nije naveden čin koji su, i ako su uopće, imali u vojsci. Uočljivo je kako su većina pokopanih vojnika bili regruti, dok među umrlima gotovo da i nema oficira/časnika. Može se samo nagađati zašto je tomu tako. Jedna od pretpostavki je da su regruti imali slabiju skrb od oficira/časnika.

Kako se radilo o vojnicima nameće se pitanje u kojim su vojnim postrojbama služili? Najviše u 36. pješadijskoj pukovniji „Jelačićc smještenoj u Varaždinu - njih 38 ili 46 posto. Ostali su služili u sljedećim postrojbama: 5. pješadijska pukovnija 10 osoba, 43. pješadijska pukovnija osam osoba, 14. topnička pukovnija šest osoba, 8. konjanička pukovnija tri osobe, Granična postrojba dvije osobe, a po jedna osoba u 4., 33. i 53. pješadijskoj pukovniji te u 3. konjaničkoj pukovniji i 21. radničkom bataljunu. Za 10 vojnika nije navedeno gdje su služili.

Što se tiče starosti, najviše preminulih vojnika bilo je između 20. i 30. godine života - 85 posto (najviše u 21. i 22. godini života). Najmlađi pokopani vojnici su 19-godišnji Milivoj Marković iz Podčepa i Stojadin Stojković iz Gnjilana, dok je najstariji bio spomenuti 78-godišnji Stevan Lapčević iz Gline. ${ }^{31}$ U svega sedam slučajeva zabilježeno je zanimanje pokojnika - svi su bili poljoprivrednici. ${ }^{32}$ Oženjenih je bilo 43 posto, neoženjenih 38 posto, tri posto su udovci, a za 13 posto vojnika taj podatak nije naveden. U par slučajeva navedeno je ime žene: za ranije spomenutog S. Lapčevića zabilježeno je da je udovac iza Marije, Božidar Trajković iz Krševice je udovac iza Stojanke, zatim Božidar Slamenković iz Miroševca oženjen je Zorkom, Jelenko Sibinović iz Nikolinca s Ružom, a Milorad Spasić iz Grdelice s Budinkom. ${ }^{33}$

U Grobnim očevidnicima zapisano je i mjesto gdje je vojnik umro. Najviše ih je umrlo u vojnoj bolnici (ili u gradskoj bolnici) gdje su bili dovedeni na liječenje. No, nisu svi tamo umrli. Milivoje Aranđelović iz Vitoševca umro je na putu u bolnicu kao žrtva vojne pobune 1919. godine, Tanasije Stevanović iz Kršne Glave i Damjan Grujo Janzulović iz Malajnice utopili su se u Dravi, pukovnik S. Lapčević umro je stanu u Kukuljevićevoj ulici, a Živorad Marković iz Sirakova u vojarni 14 . topničke pukovnije. ${ }^{34}$

Glede godina kada je umrlo najviše vojnika srpske nacionalnosti posebno se ističe 1922. - tada ih je umrlo 24 ili 29,2 posto od ukupnog broja. Uočljivo je da su većinom umrli od upale pluća i to u prvom i drugom mjesecu. Može se nagađati o uzrocima oboljenja, no jedan bi mogao biti aktivnost na otvorenom bez adekvatne obuće $\mathrm{i}$ odjeće. ${ }^{35} \mathrm{U}$ ostalim godinama prosjek umrlih je između pet do sedam vojnika godišnje dok npr. od 1924. do 1926. te 1932., 1934. i 1936. nije umro ni jedan vojnik. Ovi podaci mogu se usporediti i s uku-

\footnotetext{
${ }^{31} \mathrm{U}$ Tablici 1 vidi red. br. 4, 7 i 10.

${ }^{32} \mathrm{U}$ Tablici 1 vidi red. br. 4, 6, 21, 26, 29, 37 i 54.

${ }^{33} \mathrm{U}$ Tablici 1 vidi red. br. 10, 60, 64, 68 i 81.

${ }^{34} \mathrm{U}$ Tablici 1 vidi red. br. 1, 2, 10, 17, 51.

${ }^{35}$ Isto se dogodilo u karlovačkoj 35. pješačkoj pukovniji gdje su vojnici umirali od upale pluća i gripe. Liječnička komisija utvrdila je da je uzrok vlažno i blatno zemljište oko baraka kojim su vojnici svakodnevno hodali. Više vidi u: M. Bjelajac, Vojska Kraljevine Srba, Hrvata i Slovenaca 1918-1921, 126-127.
} 
pnim brojem umrlih vojnika u Varaždinu - 1922. umrlo ih je najviše - 34 ili 16,3 posto od ukupnog broja. I godine od završetka Velikog rata do 1922. bilježe najveću smrtnost vojnika u međuratnom razdoblju, no nakon vrhunca smrtnost se smanjuje i u prosjeku se kreće između pet do deset umrlih vojnika godišnje - sve do 1941. godine.

Svakako zanimljivi podaci su mjesta gdje su rođeni vojnici srpske nacionalnosti pokopani u Varaždinu. Ovisno o vremenu upisa i samome upisivaču, najčešće je navedeno mjesto rođenja, okrug ili srez, a od 1929. i banovina. No, katkad je naveden samo jedan od tih podataka ili je samo jedan čitljiv. Detaljni popis nalazi se u Tablici 1, dok su u ovoj analizi korišteni podaci o rođenju vojnika na razini većeg mjesta u okrugu ili srezu. Po tome najviše vojnika je rođeno u Požarevcu - 11, zatim Valjevu pet, Gnjilanu, Kruševcu, Smederevu i Užicu četiri, a u Takovu tri. Po dvije osobe rođene su u mjestima Azbukovica, Bitolj, Palanka, Pančevo i Žiča, a po jedna osoba u mjestima Arilje, Babušnica, Bač, Badovinci, Beograd, Bijeljina, Bregovi, Bučumet, Glina, Jablanica, Jasenak, Klinovac, Konjuša, Kragujevac, Leskovac, Lugavčina, Ljutoglava, Mačkovac, Malajnica, Kotor Varoš, Naupare, Petrovac, Podrinje, Poljanica, Poreč, Sirakovo, Soko Banja, Sovljak, Šabac, Tabanović, Tetovo, Trepča, Vlasotince, Vršac, Vučitrn i Vujetinci. Podaci iz priloženog popisa pokazuju velike razlike u broju preminulih vojnika rođenih na tlu predratne Kraljevine Srbije i onih iz drugih dijelova Kraljevine SHS/Jugoslavije.

Iako su svi od navedenih vojnika pokopani u Varaždinu, za samo četiri vojnika određena je ekshumacija. Prvi je već više puta spomenuti pukovnik S. Lapčević koji je na istom groblju preseljen u drugu grobnicu, zatim Miloslav Simonović iz Požarevca preseljen je u zavičaj, Arsen Lelić je 10-ak dana nakon pogreba prenijet u Šabac, a Živko Simić mjesec dana nakon pogreba u Beograd. ${ }^{36}$ Trošak ekshumacije i prijevoza tijela ili zemnih ostataka u zavičaj odobren je na osobni zahtjev obitelji koja je plaćala sve troškove. Seljačke obitelji teško su si mogle priuštiti takav trošak te je ekshumacija bila rijetka. Također, vojnici su se pokapali u Varaždinu i zbog običaja tj. vojnik se pokapao u mjestu gdje je umro. Ekshumacija je pojava suvremenog doba.

U analizi podataka treba se osvrnuti i na uzroke smrti među vojnicima. Najviše ih je umrlo od bolesti pluća (tuberkuloze, embolije, upale, krupozne, kataralne) - 44 osobe ili 54 posto, zatim od bolesti srca i prostrijelih rana šest osoba, meningitisa i šarlaha četiri, raznih upala (npr. potrbušnice) i utapanja tri osobe, a po dvije osobe umrle su od problema s crijevima, sepse i povrede glave. U tri slučajeva uzrok smrti javio se jednom: od dizenterije je umro Slavko Šušić iz Žiče, od gangrene Ljubomir Ivanović iz Smedereva, a od gripe Milan Jeremić iz Lugavčine. ${ }^{37} \mathrm{Za}$ tri vojnika ne zna se uzrok smrti.

Proučeno arhivsko gradivo ne daje podatke o kvaliteti prehrane tj. je li bilo kakvih nedostataka. No, u jednom dopisu načelnik Grada Varaždina obraća se Dragiši Cvetkoviću, tadašnjem ministru socijalne politike i narod-

\footnotetext{
${ }^{36} \mathrm{U}$ Tablici 1 vidi red. br. 10, 54, 35 i 70.

${ }^{37} \mathrm{U}$ Tablici 1 vidi red. br. 15,62 i 67.
} 
nog zdravlja, u kojem ističe sljedeće: „Već pred 14-15 godina pojavila se je u okolici grada Varaždina dotada ovdje nepoznata bolest malarija - dolaskom vojnika iz malaričnih krajeva (...) ta se je bolest sve većma širila, dok nije u zadnje vrijeme postigla karakter epidemije! (...), a zahvatila je i najzdraviji ljudski elemenat „našu vojsku“. U varaždinskim kasarnama kamo su momci došli zdravi, sada hara malarija, a bilo je i smrtnih slučajeva! Varaždin i okolica sa Medjimurjem danas je opasan malarički kraj - kao mnoga mjesta u Južnoj Srbiji što zadaje teške brige ovdašnjim civilnim i vojnim vlastima. Sam komandant mesta, a i komandant IV. armijske oblasti zainteresovali su se svojski za ovu pojavu i gospoda generali teško (su) zabrinuti za sudbinu i zdravlje svojih vojnika. (...) Ne može kr. Vladi biti ravnodušno raspoloženje narodnih masa u ovim krajevima jer ne može trpjeti da mladi zdravi ljudi dolaze u Varaždin n. pr. na odsluženje vojnog roka, a vraćaju se kući bolesni, slabi, izmoždeni, zaraženi malarijom. Sa kakovim oduševljenjem će mladići dolaziti na vojnu dužnost kad znaju da ih tu čeka zaraza, a možda i smrt? (...)“.38

$\mathrm{Na}$ kraju, što se dogodilo s grobovima svih preminulih vojnika? Mjesto na kojem su pokopani vojnici žrtve Velikog rata je uredno održavano, a u povodu 100. obljetnice završetka Prvog svjetskog rata postavljena je prigodna spomen ploča. Odmah do tog spomen obilježja, a u III. polju, pokapani su vojnici umrli u Varaždinu u međuratnom razdoblju. Kada se taj dio polja gotovo popunio, vojnici su pokapani najviše u VIII. polju. Kada je počeo Drugi svjetski rat, na vojnički dio III. i VIII. polja počeli su se pokapati pripadnici ustaške vojnice, domobranstva te njemački i talijanski vojnici. Po završetku rata 1945., nova socijalistička vlast naredila je uništenje svih grobova ratnih neprijatelja. U tom uništenju moguće je da su preostali neki vojni grobovi u III. polju, ali nova vlast nije brinula o njima te su ubrzo zarasli i propali. Nakon toga grobna mjesta prodana su građanima. Do danas se ništa nije sačuvalo i nema nikakvih naznaka da su na tom mjestu ikada bili pokapani vojnici između dva svjetska rata.

\footnotetext{
${ }^{38}$ HR-DAVŽ, GPV PS 1936.-1938., kut. br. 22., 1938. Na dokumentu je oznaka: 214/ 1938. Pov.
} 


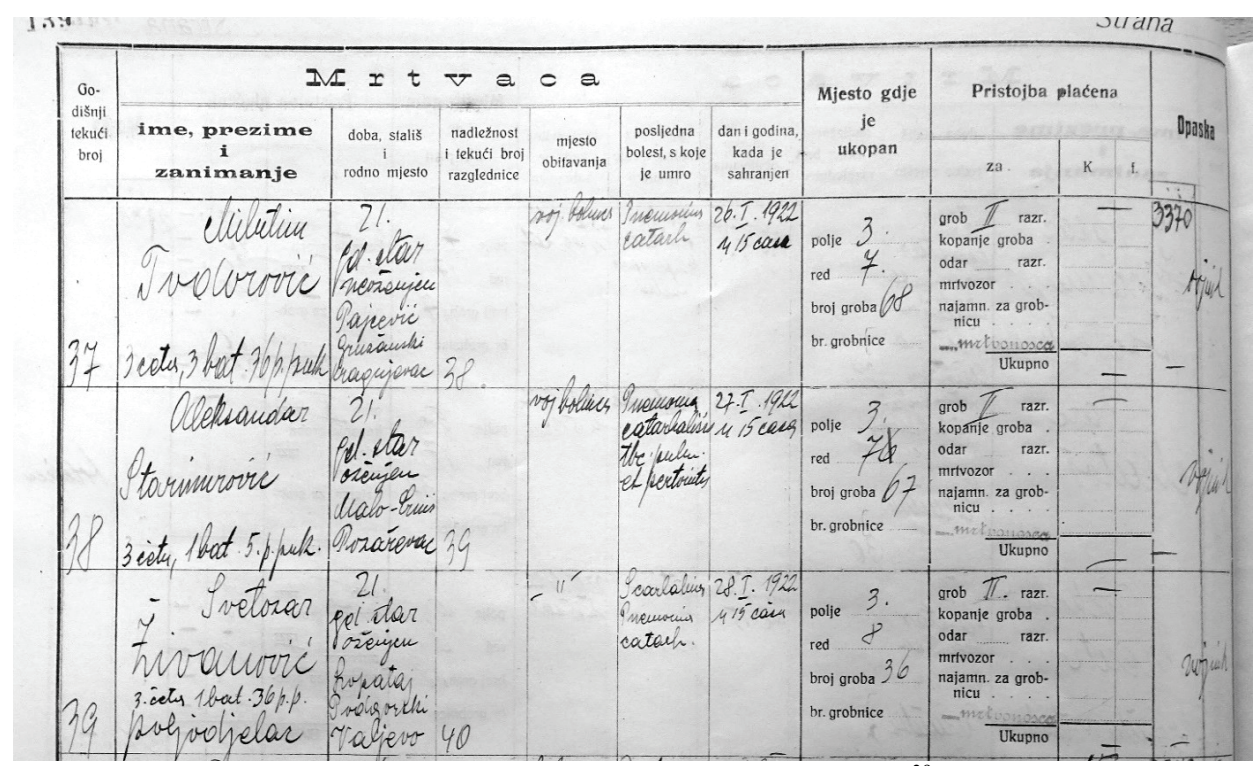

Primjer upisa podataka u Grobnom očevidniku ${ }^{39}$

Kaplar, $1,1 \%$

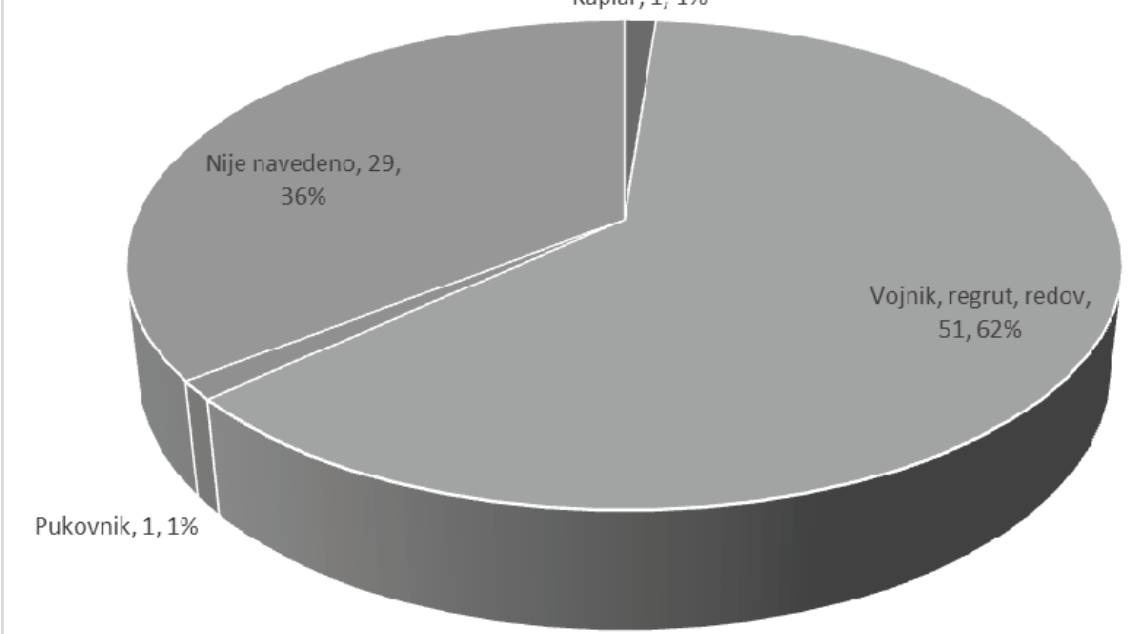

Grafikon 1. Činovi pokopanih vojnika

${ }^{39}$ Parkovi d. d., „Grobni očevidnik (1919.-1939.)“, str. 139. 


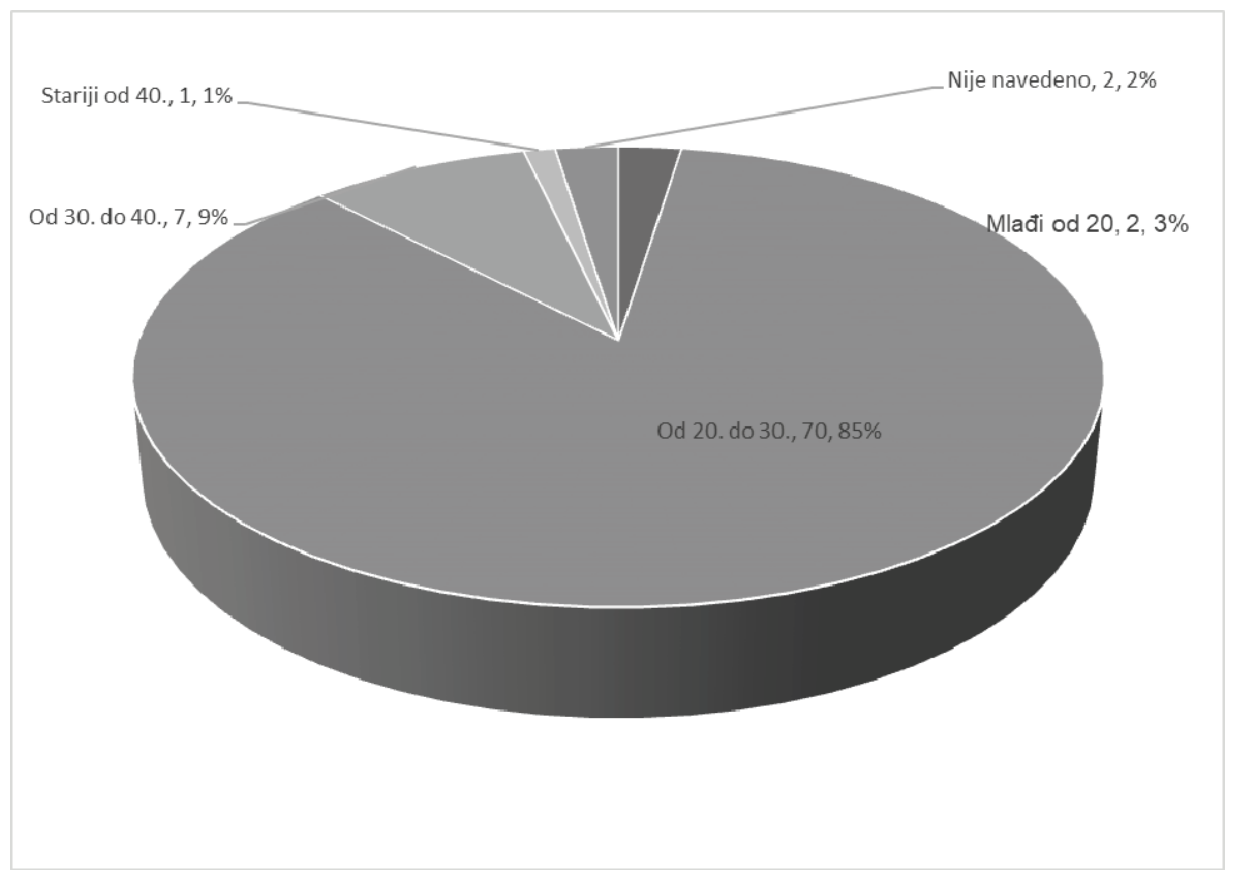

Grafikon 2. Dob pokopanih vojnika

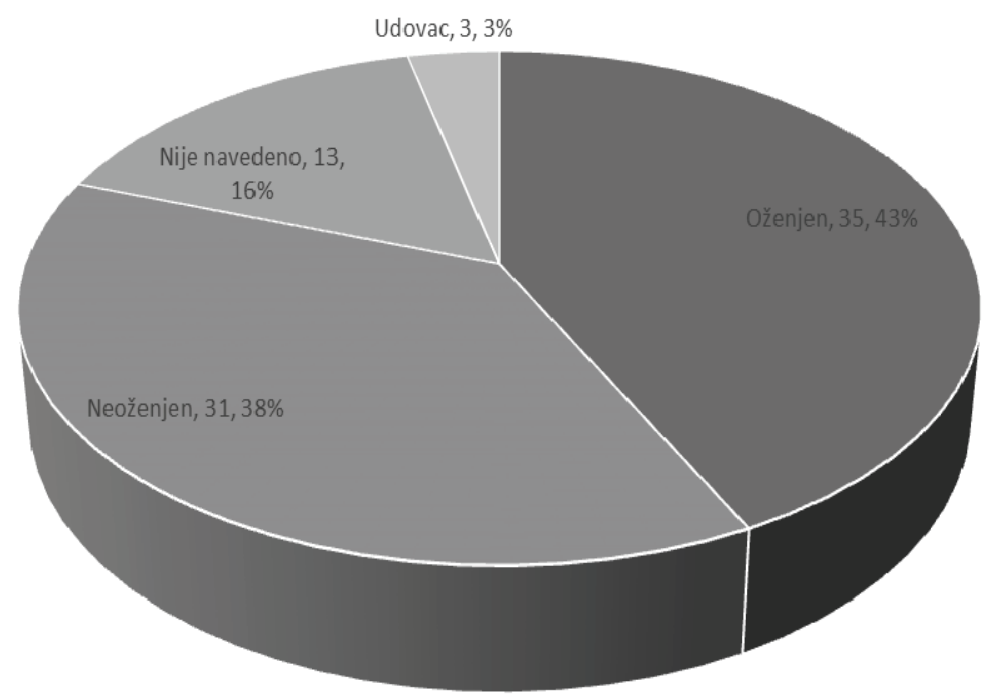

Grafikon 3. Bračno stanje pokopanih vojnika 


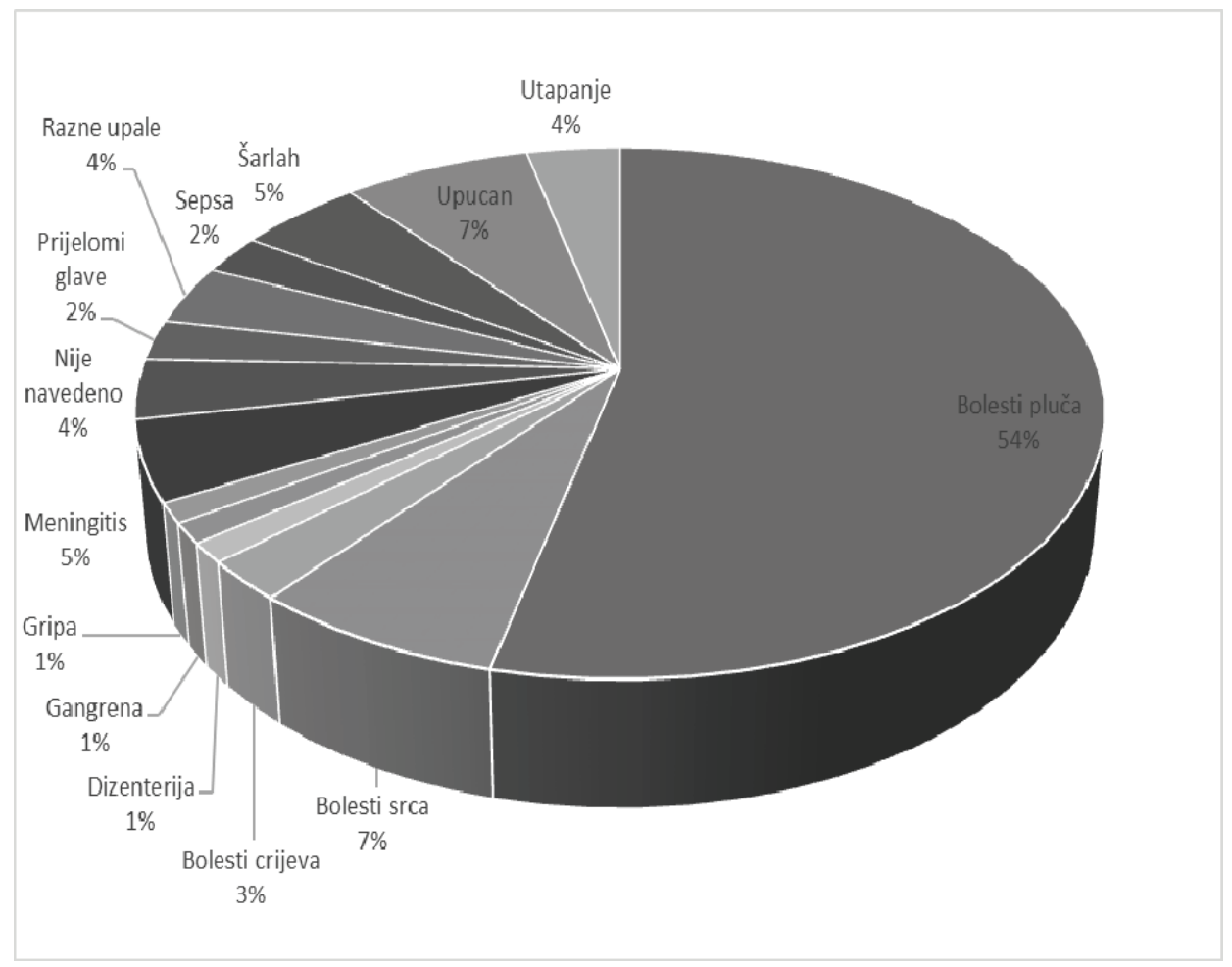

Grafikon 4. Uzrok smrti pokopanih vojnika

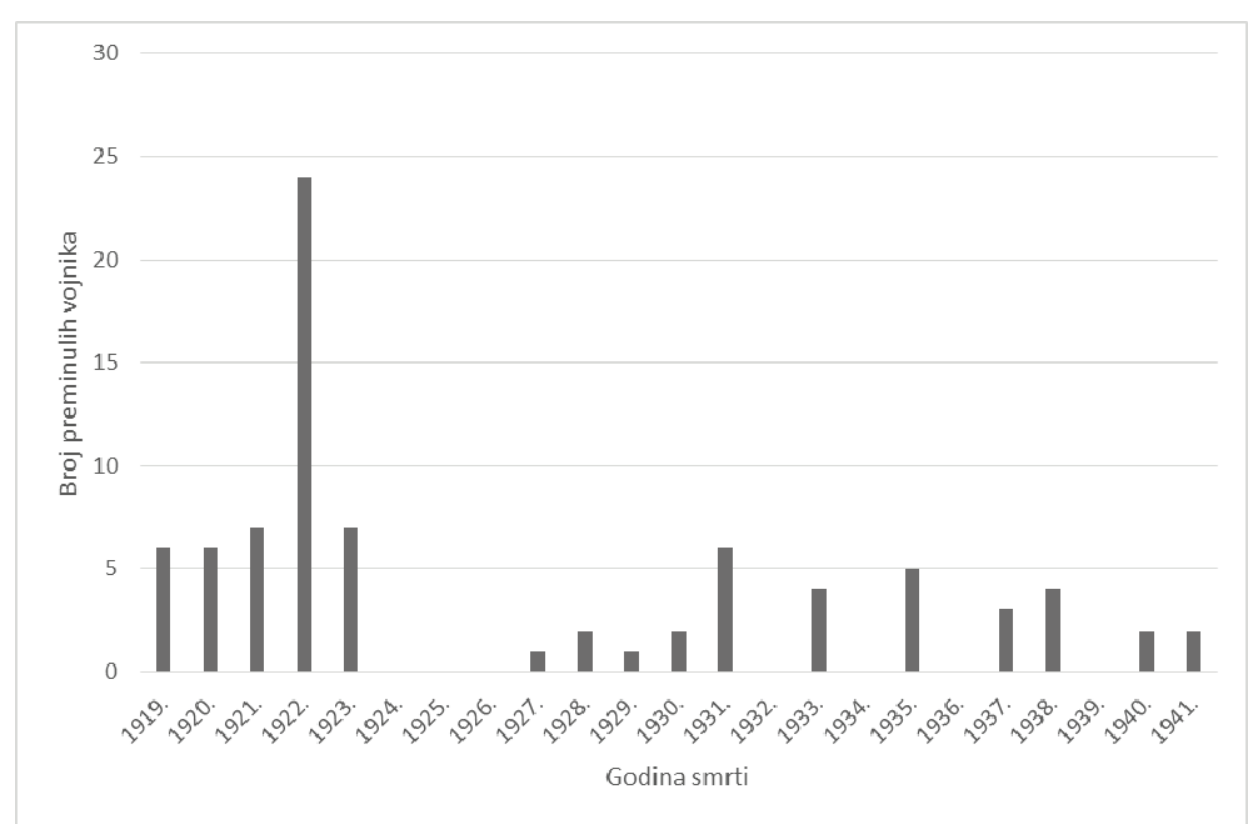

Grafikon 5. Broj preminulih vojnika po godinama 


\section{Zaključak}

U radu su obrađeni podaci vojnika srpske nacionalnosti koji su između Prvog i Drugog svjetskog rata bili pokopani na varaždinskom groblju. Od ukupnog broja pokopanih vojnika srpske nacionalnosti gotovo svi su bili vojnici Kraljevine SHS/Jugoslavije, osim jednog koji je sigurno služio u vojsci AustroUgarske Monarhije, no za njega nema podataka je li se u mirovini ponovno aktivirao. Izvorni podaci preuzeti su iz arhivskih knjiga Grobni očevidnik (1919.-1939.) i Grobni očevidnik (1940.-1949.) koje čuva gradska komunalna tvrtka Parkovi d. d.

U međuratnom razdoblju na varaždinskom groblju pokopano je ukupno 208 vojnika, među kojima 82 srpske nacionalnosti. Zahvaljujući podacima iz navedenih arhivskih knjiga poznat nam je njihov identitet - ime, prezime, starost, bračno stanje, mjesto rođenja i bolest od koje su umrli. Najveći broj pokopanih vojnika, njih 62 posto, bili su regruti te samo jedan 78-godišnji časnik koji je bio umirovljenik Austro-ugarske vojske. Najviše pokopanih vojnika umrlo je u 21. ili 22. godini života i služilo je, najvećim djelom, u varaždinskom 36. pješadijskoj pukovniji „Jelačić““. Gotovo svi vojnici umrli su u lokalnoj vojnoj ili gradskoj bolnici, a svega nekoliko njih drugdje. Što se tiče zavičaja vojnika najviše ih je rođeno u Požarevcu - 11, zatim u Valjevu pet, u Gnjilanu, Kruševcu, Smederevu i Užicu četiri, Takovu tri, a u ostalim mjestima po jedna ili dvije osobe. Pokopani vojnici najviše su umirali od bolesti pluća - čak 54 posto, zatim od bolesti srca i prostrijelih rana sedam posto, šarlaha i meningitisa pet posto te utapanja četiri posto. Ostale bolesti zabilježene su u manjem postotku ili su se dogodile jednom kao gripa, gangrena ili dizenterija.

Vojnici su bili pokapani na III. i VIII. polju varaždinskog groblja. Kada je počeo Drugi svjetski rat na ta polja pokapali su se pripadnici ustaške vojnice, domobranstva kao i njemački te talijanski vojnici. Po završetku rata nova socijalistička vlast uništila je grobove ratnih neprijatelja. Moguće je da su preostali neki vojni grobovi u III. polju, ali nova vlast nije brinula o njima te su ubrzo propali. Nakon toga grobna mjesta su prodana. Danas nema nikakvih naznaka da su na tom mjestu ikada bili pokapani vojnici u mirnodopskom razdoblju između dva svjetska rata. 
PRILOG

Tablica 1. Popis srpskih vojnika pokopanih na varaždinskom groblju (1919.-1941.) ${ }^{40}$

\begin{tabular}{|c|c|c|c|c|c|c|c|}
\hline $\begin{array}{l}\text { Re- } \\
\text { dni } \\
\text { broj }\end{array}$ & \begin{tabular}{|c|} 
Godi- \\
šnji \\
tekući \\
broj
\end{tabular} & $\begin{array}{c}\text { Ime, prezime } \\
\text { i zanimanje }\end{array}$ & $\begin{array}{l}\text { Doba, stališ i } \\
\text { rodno mjesto }\end{array}$ & $\begin{array}{c}\text { Mjesto } \\
\text { obitava- } \\
\text { nja }\end{array}$ & $\begin{array}{l}\text { Posljednja } \\
\text { bolest od } \\
\text { koje je } \\
\text { umro }\end{array}$ & $\begin{array}{l}\text { Dan i godina } \\
\text { kada je sah- } \\
\text { ranjen }\end{array}$ & $\begin{array}{l}\text { Mjesto } \\
\text { gdje } \\
\text { je uko- } \\
\text { pan }\end{array}$ \\
\hline 1 & 178 & $\begin{array}{l}\text { Milivoje } \\
\text { Arandjelović } \\
\text { redov 4. čete } \\
\text { 4. batalj. IV. } \\
\text { pješ. puka }{ }^{41}\end{array}$ & $\begin{array}{c}\text { ? star } \\
\text { Vitoševac } \\
\text { Ražanjski } \\
\text { Kruševac }\end{array}$ & $\begin{array}{l}\text { na putu u } \\
\text { vojn. } \\
\text { bolnicu }\end{array}$ & $\begin{array}{c}\text { ustrijeljen } \\
23.7 .1919 .\end{array}$ & $\begin{array}{c}\text { 24. 7. } 1919 . \\
\text { u } 16 \text { sati }\end{array}$ & $\begin{array}{c}\text { polje } 3 \\
\text { red } 7 \\
\text { broj groba } \\
50\end{array}$ \\
\hline 2 & 205 & $\begin{array}{c}\text { Tanasije } \\
\text { Stevanović } \\
\text { redov V. peš. } \\
\text { puka }\end{array}$ & $\begin{array}{c}36 \text { god. star } \\
\text { Kršna Glava } \\
\text { Valjevo }\end{array}$ & Drava & $\begin{array}{c}\text { utopio se } 20 . \\
8.1919 .\end{array}$ & $\begin{array}{c}\text { 24. 8. } 1919 . \\
\text { u } 4 \text { sata }\end{array}$ & $\begin{array}{c}\text { polje } 3 \\
\text { red } 7 \\
\text { broj groba } \\
46\end{array}$ \\
\hline 3 & 209 & $\begin{array}{l}\text { Vladimir } \\
\text { Rakić } \\
\text { redov 5. pp. } \\
\text { puka } \\
\end{array}$ & $\begin{array}{l}35 \text { god. star } \\
\text { Valjevo }\end{array}$ & $\begin{array}{l}\text { Gr. bolni- } \\
\text { ca }\end{array}$ & \begin{tabular}{|c|} 
Invaginato \\
coecolis \\
tumor olei \\
ileus \\
\end{tabular} & $\begin{array}{c}\text { 1.9. } 1919 . \\
\text { u } 15 \text { sati }\end{array}$ & $\begin{array}{c}\text { polje } 3 \\
\text { red } 7 \\
\text { broj groba } \\
45 \\
\end{array}$ \\
\hline 4 & 277 & $\begin{array}{l}\text { Milivoj Mar- } \\
\text { ković } \\
\text { vojnik (ratar) }\end{array}$ & $\begin{array}{l}19 \text { god. star } \\
\text { neoženjen } \\
\text { Podčep } \\
\text { Užički, Srbija }\end{array}$ & $\begin{array}{l}\text { vojn. } \\
\text { bolnica }\end{array}$ & $\begin{array}{r}\text { klijenut srca, } \\
\text { upala pluća } \\
\text { i mana srdca }\end{array}$ & $\begin{array}{c}\text { 17. } 12.1919 . \\
\text { u } 15 \text { sati }\end{array}$ & $\begin{array}{c}\text { polje } 3 \\
\text { red } 7 \\
\text { broj groba } \\
11\end{array}$ \\
\hline 5 & 302 & $\begin{array}{l}\text { Ilija Đorđe } \\
\text { Dumbić } \\
\text { regrut } 43 . \\
\text { pješ. puka I. } \\
\text { bat. }\end{array}$ & $\begin{array}{c}31 \text { god. star } \\
\text { neoženjen } \\
\text { srez i okrug } \\
\text { Bitolj, Srbija }\end{array}$ & $\begin{array}{l}\text { priv. vojna } \\
\text { bolnica }\end{array}$ & $\begin{array}{c}\text { Pneumoni- } \\
\text { um } \\
\text { dextra }\end{array}$ & $\begin{array}{c}\text { 17. } 12.1919 . \\
\text { u } 15 \text { sati }\end{array}$ & $\begin{array}{c}\text { polje } 3 \\
\text { red } 7 \\
\text { broj groba } \\
10\end{array}$ \\
\hline 6 & 308 & $\begin{array}{c}\text { Pante Dimitri- } \\
\text { je } \\
\text { Djordjević } \\
\text { ratar (redov) }\end{array}$ & $\begin{array}{l}\text { ? oženjen } \\
\text { Resanski } \\
\text { Bitoljski }\end{array}$ & $\begin{array}{l}\text { voj. bolni- } \\
\text { ca }\end{array}$ & $\begin{array}{l}\text { Aedena } \\
\text { pluća }\end{array}$ & $\begin{array}{c}22.12 .1919 . \\
\text { u } 15 \text { sati }\end{array}$ & $\begin{array}{c}\text { polje } 3 \\
\text { red } 7 \\
\text { broj groba } \\
9\end{array}$ \\
\hline 7 & 14 & $\begin{array}{l}\text { Stojadin Đor- } \\
\text { djin Stojković } \\
\text { regrut } 43 . \\
\text { pješ. puka } 4 . \\
\text { čete }\end{array}$ & $\begin{array}{l}19 \text { god. star } \\
\text { oženjen } \\
\text { (?) Gilan } \\
\text { Kosovski }\end{array}$ & $\begin{array}{l}\text { voj. bolni- } \\
\text { ca }\end{array}$ & $\begin{array}{c}\text { Pleuro } \\
\text { Pneumonia } \\
\text { dextra }\end{array}$ & $\begin{array}{c}\text { 10. } 1.1920 . \\
\text { u } 15 \text { sati }\end{array}$ & $\begin{array}{c}\text { polje } 3 \\
\text { red } 6 \\
\text { broj groba } \\
12\end{array}$ \\
\hline 8 & 22 & $\begin{array}{l}\text { S. Stojadin } \\
\text { Mihajlović } \\
\text { regrut 43. pješ. } \\
\text { puka 2. čete, } \\
\text { regr. bata. }\end{array}$ & $\begin{array}{l}23 \text { god. star } \\
\text { oženjen } \\
\text { (?) Gilan } \\
\text { Kosovski }\end{array}$ & $\begin{array}{l}\text { voj. bolni- } \\
\text { ca }\end{array}$ & $\begin{array}{l}\text { Pneumonia } \\
\text { catarhalis }\end{array}$ & $\begin{array}{l}\text { 13. I. } 1920 . \\
\text { u } 15 \text { sati }\end{array}$ & $\begin{array}{c}\text { polje } 3 \\
\text { red } 6 \\
\text { broj groba } \\
39\end{array}$ \\
\hline
\end{tabular}

${ }^{40}$ Podaci u Tablici 1 prepisani su u izvornom obliku iz knjiga „Grobni očevidnik (1919.-1939.)“ i „Grobni očevidnik (1940.-1949.)“ koje se čuvaju u gradskoj komunalnoj tvrtki Parkovi d. d. Varaždin. Različiti su bili upisi mjeseca kada je osoba pokopana npr. „V“, „5.“ ili „svibanj““. Ovdje je prilagođeno u arapske brojke. U stupcu „Dan i godina kada je sahranjen“ različito se upotrebljavaju pojmovi ,sati“ i , „časovi“. Ovdje je prilagođeno u „sati“.

${ }^{41}$ Stradali vojnik u vojnoj pobuni 23. srpnja 1919. godine. 


\begin{tabular}{|c|c|c|c|c|c|c|c|}
\hline 9 & 69 & $\begin{array}{l}\text { Veljko Stoj- } \\
\text { ković } \\
\text { redov } 43 \text {. pješ. } \\
\text { puka, } 1 . \text { bat. } 1 . \\
\text { četa }\end{array}$ & $\begin{array}{l}34 \text { god. star } \\
\text { (?) Gilan } \\
\text { Kosovski }\end{array}$ & $\begin{array}{l}\text { vojn. } \\
\text { bolnica }\end{array}$ & $\begin{array}{l}\text { Marbus } \\
\text { brighti (?) } \\
\text { tbc pulm. }\end{array}$ & $\begin{array}{c}\text { 18. } 2.1920 . \\
\text { u } 15 \text { sati }\end{array}$ & $\begin{array}{c}\text { polje } 3 \\
\text { red } 6 \\
\text { broj groba } \\
26\end{array}$ \\
\hline 10 & 81 & $\begin{array}{c}\text { Stevan Lap- } \\
\text { čević }^{42} \\
\text { pukovnik u m. }\end{array}$ & $\begin{array}{l}78 \text { god. star } \\
\text { udovac iza } \\
\text { Marije, (?) } \\
\text { kod Gline }\end{array}$ & $\begin{array}{c}\text { Kukulje- } \\
\text { vićeva } \\
28\end{array}$ & $\begin{array}{l}\text { Arteriosclo- } \\
\text { rouis, } \mathrm{Pa}- \\
\text { ralysis } \\
\text { cordis }\end{array}$ & $\begin{array}{l}\text { 26. II. } 1920 . \\
\text { u } 16 \text { sati }\end{array}$ & $\begin{array}{c}\text { polje } 3 \\
\text { red } 5 \\
\text { broj groba } \\
31\end{array}$ \\
\hline 11 & 115 & $\begin{array}{l}\text { Stevan Marti- } \\
\text { nović } \\
\text { redov 3. čete } \\
\text { 3. bata., } 43 \text {. p. } \\
\text { puk. }\end{array}$ & $\begin{array}{c}34 \text { god. star } \\
\text { udovac } \\
\text { Vršac }\end{array}$ & $\begin{array}{l}\text { vojn. } \\
\text { bolnica }\end{array}$ & $\begin{array}{l}\text { Pneumonia } \\
\text { capilaris } \\
\text { esciephare } \\
(?)\end{array}$ & $\begin{array}{c}\text { 25. III. } 1920 . \\
\text { u } 10 \text { sati }\end{array}$ & $\begin{array}{c}\text { polje } 3 \\
\text { red } 6 \\
\text { broj groba } \\
29\end{array}$ \\
\hline 12 & 334 & $\begin{array}{l}\text { Aleksandar } \\
\text { Vinković } \\
\text { 3. eskadron } 3 . \\
\text { konj. puk. }\end{array}$ & $\begin{array}{l}21 \text { god. star } \\
\text { Vodice Jase- } \\
\text { nački } \\
\text { Smederevo }\end{array}$ & $\begin{array}{l}\text { vojn. } \\
\text { bolnica }\end{array}$ & $\begin{array}{l}\text { Prelom } \\
\text { lubanje, } \\
\text { ozljeda } \\
\text { mozga }\end{array}$ & $\begin{array}{c}29.12 .1920 . \\
\text { u } 10 \text { sati }\end{array}$ & $\begin{array}{c}\text { polje } 3 \\
\text { red } 6 \\
\text { broj groba } \\
36\end{array}$ \\
\hline 13 & 98 & $\begin{array}{c}\text { Dragomir } \\
\text { Nikolić } \\
\text { redov jurišne } \\
\text { čete } \\
\text { 43. pješ. puka }\end{array}$ & $\begin{array}{l}24 \text { god. star } \\
\text { oženjen } \\
\text { Ružanj } \\
\text { Vračarski } \\
\text { Beogradski }\end{array}$ & $\begin{array}{l}\text { vojn. } \\
\text { bolnica }\end{array}$ & Tbc. pulm. & $\begin{array}{c}21.3 .1921 . \\
\text { u } 15 \text { sati }\end{array}$ & $\begin{array}{c}\text { polje } 3 \\
\text { red } 6 \\
\text { broj groba } \\
63\end{array}$ \\
\hline 14 & 109 & $\begin{array}{l}\text { Radoslav } \\
\text { Haraklaić } \\
\text { redov 3. čete } \\
\text { 1. bat., } \\
\text { 36. pješ. puk. }\end{array}$ & $\begin{array}{l}21 \text { god. star } \\
\text { neoženjen } \\
\text { Šarenik } \\
\text { Moravički } \\
\text { Bačanski }\end{array}$ & $\begin{array}{l}\text { vojn. } \\
\text { bolnica }\end{array}$ & $\begin{array}{l}\text { Pneumonia } \\
\text { crouposa }\end{array}$ & $\begin{array}{c}\text { 26. 3. } 1921 . \\
\text { u } 15 \text { sati }\end{array}$ & $\begin{array}{c}\text { polje } 3 \\
\text { red } 6 \\
\text { broj groba } \\
64\end{array}$ \\
\hline 15 & 156 & $\begin{array}{c}\text { Ljubomir } \\
\text { Ivanović } \\
\text { redov } 2 \text {. čet. } 2 . \\
\text { bat. } \\
\text { 43. pješ. puk. }\end{array}$ & $\begin{array}{c}21 \text { god. star } \\
\text { neoženjen } \\
\text { Stari (?) Sme- } \\
\text { derevo }\end{array}$ & $\begin{array}{l}\text { voj. bolni- } \\
\text { ca }\end{array}$ & $\begin{array}{c}\text { gangrena } \\
\text { petunora (?) }\end{array}$ & $\begin{array}{c}\text { 2. } 6.1921 . \\
\text { u } 17 \text { sati }\end{array}$ & $\begin{array}{c}\text { polje } 3 \\
\text { red } 6 \\
\text { broj groba } \\
73\end{array}$ \\
\hline 16 & 208 & $\begin{array}{l}\text { Dragiša Ro- } \\
\text { ković } \\
\text { redov } 1 . \text { čete } 3 \\
\text { bat. } \\
\text { 43. pješ. puk. }\end{array}$ & $\begin{array}{l}21 \text { god. star } \\
\text { (?) Takovski } \\
\text { Rudnički }\end{array}$ & $\begin{array}{l}\text { vojn. } \\
\text { bolnica }\end{array}$ & $?$ & $\begin{array}{c}\text { 24. 6. } 1921 . \\
\text { u } 18 \text { sati }\end{array}$ & $\begin{array}{c}\text { polje } 3 \\
\text { red } 7 \\
\text { broj groba } \\
35\end{array}$ \\
\hline 17 & 218 & $\begin{array}{l}\text { Damjan Grujo } \\
\text { Janzulović } \\
\text { redov 3/ I. } \\
\text { čete, } \\
\text { 36. pješ. puk. }\end{array}$ & $\begin{array}{l}21 \text { god. star } \\
\text { Laznica Poža- } \\
\text { revac }\end{array}$ & $\begin{array}{c}\text { Utopio se } \\
\text { u } \\
\text { Dravi } \\
\text { prilikom } \\
\text { kupanja } \\
\end{array}$ & Utopio se & $\begin{array}{c}\text { 3. } 7.1921 . \\
\text { u } 10 \text { sati }\end{array}$ & $\begin{array}{c}\text { polje } 3 \\
\text { red } 7 \\
\text { broj groba } \\
43\end{array}$ \\
\hline 18 & 222 & $\begin{array}{l}\text { Gjordje M. } \\
\text { Stevanović } \\
\text { redov mitra- } \\
\text { ljez. odelenje } \\
\text { 36. pješ. puka } \\
\text { Jelačić }\end{array}$ & $\begin{array}{c}21 \text { god. star } \\
\text { Malajnica (?) }\end{array}$ & $\begin{array}{l}\text { vojn. } \\
\text { bolnica } \\
68\end{array}$ & Peritonitis & $\begin{array}{l}\text { 6. } 7.1921 . \\
\text { u } 15 \text { sati }\end{array}$ & $\begin{array}{c}\text { polje } 3 \\
\text { red } 7 \\
\text { broj groba } \\
42\end{array}$ \\
\hline
\end{tabular}

${ }^{42}$ Napomena iz Grobnog očevidnika: „Ekshumiran i pokopan u grobnicu br. 36“. 
Istorija 20. veka, god. 38, 2/2020, 61-84

\begin{tabular}{|c|c|c|c|c|c|c|c|}
\hline 19 & 248 & $\begin{array}{l}\text { Djordje Vuka- } \\
\text { šinović } \\
\text { redov } 1 / 1 \\
\text { čete, } \\
\text { 36. pješ. puka } \\
\text { Jelačić }\end{array}$ & $\begin{array}{c}21 \text { god. star } \\
? \\
\text { (?) Podunav- } \\
\text { ski Smederev- } \\
\text { ski }\end{array}$ & $\begin{array}{l}\text { vojn. } \\
\text { bolnica }\end{array}$ & Sepsis & $\begin{array}{c}28.7 .1921 . \\
\text { u } 9 \text { sati }\end{array}$ & $\begin{array}{c}\text { polje } 3 \\
\text { red } 7 \\
\text { broj groba } \\
30\end{array}$ \\
\hline 20 & 4 & $\begin{array}{l}\text { Živko Grujić } \\
\text { 2. eskadron } \\
\text { 8. konjički } \\
\text { puk }\end{array}$ & $\begin{array}{l}21 \text { god. star } \\
\text { neoženjen } \\
\text { Bratarac (?) } \\
\text { Požarevački }\end{array}$ & $\begin{array}{l}\text { vojn. } \\
\text { bolnica }\end{array}$ & $\begin{array}{l}\text { Pneumonia } \\
\text { cropuosa }\end{array}$ & $\begin{array}{l}\text { 9. } 1.1922 \text {. } \\
\text { u } 141 / 2 \text { sati }\end{array}$ & $\begin{array}{c}\text { polje } 3 \\
\text { red } 7 \\
\text { broj groba } \\
29\end{array}$ \\
\hline 21 & 16 & $\begin{array}{c}\text { Milovan } \\
\text { Vasiljević } \\
\text { 1. četa 1. bat. } \\
5 \text { p. puka } \\
\text { poljodjelac }\end{array}$ & $\begin{array}{l}21 \text { god. star } \\
\text { neoženjen } \\
\text { Trepče, Lju- } \\
\text { binski Rudni- } \\
\text { čki }\end{array}$ & $\begin{array}{l}\text { vojn. } \\
\text { bolnica }\end{array}$ & $\begin{array}{l}\text { Pneumonia } \\
\text { katarhalis }\end{array}$ & $\begin{array}{c}\text { 17. } 1.1922 . \\
\text { u } 15 \text { sati }\end{array}$ & $\begin{array}{c}\text { polje } 3 \\
\text { red } 7 \\
\text { broj groba } \\
74\end{array}$ \\
\hline 22 & 21 & $\begin{array}{c}\text { Dragoljub } \\
\text { Arnautović } \\
\text { 2. četa } 1 \text { bat. } 5 \\
\text { p. p }\end{array}$ & $\begin{array}{l}\text { 21. god. star } \\
\text { oženjen } \\
\text { Badovinci } \\
\text { Mačvanski } \\
\text { Podrinski } \\
\end{array}$ & $\begin{array}{l}\text { vojn. } \\
\text { bolnica }\end{array}$ & $\begin{array}{l}\text { Pneumonia } \\
\text { catarhalis }\end{array}$ & $\begin{array}{c}\text { 20. } 1.1922 . \\
\text { u } 11 \text { sati }\end{array}$ & $\begin{array}{c}\text { polje } 3 \\
\text { red } 7 \\
\text { broj groba } \\
73\end{array}$ \\
\hline 23 & 22 & $\begin{array}{l}\text { Živko Mitro- } \\
\text { vić } \\
\text { 3. četa } 1 . \text { bat. } \\
\text { 5. p. p. }\end{array}$ & $\begin{array}{l}21 \text { god. star } \\
\text { neoženjen } \\
\text { Trnjani } \\
\text { Požarevački }\end{array}$ & (isto) & (isto) & $\begin{array}{c}20.1 .1922 . \\
\text { u } 11 \text { sati }\end{array}$ & $\begin{array}{c}\text { polje } 3 \\
\text { red } 7 \\
\text { broj groba } \\
71\end{array}$ \\
\hline 24 & 23 & $\begin{array}{c}\text { Dragutin } \\
\text { Mitković } \\
\text { 2. četa 1. bat. } \\
\text { 5. pp. }\end{array}$ & $\begin{array}{c}21 \text { god. star } \\
\text { (?) } \\
\text { Požarevac }\end{array}$ & (isto) & (isto) & $\begin{array}{c}20.1 .1922 . \\
\text { u } 11 \text { sati }\end{array}$ & $\begin{array}{c}\text { polje } 3 \\
\text { red } 7 \\
\text { broj groba } \\
69 \\
\end{array}$ \\
\hline 25 & 31 & $\begin{array}{l}\text { Aleksandar } \\
\text { Stanković } \\
\text { 3. četa 1. bat. } \\
\text { 5. p. p. }\end{array}$ & $\begin{array}{l}21 \text { god. star } \\
\text { oženjen } \\
\text { Topolnica } \\
\text { Požarevac }\end{array}$ & $\begin{array}{l}\text { vojn. } \\
\text { bolnica }\end{array}$ & $\begin{array}{c}\text { Pneumonia } \\
\text { katarhalis }\end{array}$ & $\begin{array}{c}23.1 .1922 . \\
\text { u } 15 \text { sati }\end{array}$ & $\begin{array}{c}\text { polje } 3 \\
\text { red } 7 \\
\text { broj groba } \\
72\end{array}$ \\
\hline 26 & 33 & $\begin{array}{l}\text { Tihomir Mit- } \\
\text { rović } \\
\text { poljodjelac } \\
\text { 2. četa } 1 . \text { bat. } \\
\text { 36. p. p. } \\
\end{array}$ & $\begin{array}{l}21 \text { god. star } \\
\text { oženjen } \\
\text { (?) Azbukovi- } \\
\text { ca Podrinski }\end{array}$ & $\begin{array}{l}\text { vojn. } \\
\text { bolnica }\end{array}$ & $\begin{array}{c}\text { Pneumonia } \\
\text { catarhalis }\end{array}$ & $\begin{array}{c}\text { 23. } 1.1922 . \\
\text { u } 15 \text { sati }\end{array}$ & $\begin{array}{c}\text { polje } 3 \\
\text { red } 7 \\
\text { broj groba } \\
72\end{array}$ \\
\hline 27 & 37 & $\begin{array}{l}\text { Milutin Todo- } \\
\text { rović } \\
\text { 3. četa 3. bat. } \\
\text { 36. p. puk. }\end{array}$ & $\begin{array}{l}21 \text { god. star } \\
\text { oženjen } \\
\text { Pajsijević } \\
\text { Gružanski } \\
\text { Kragujevac }\end{array}$ & $\begin{array}{l}\text { vojn. } \\
\text { bolnica }\end{array}$ & $\begin{array}{c}\text { Pneumonia } \\
\text { (?) }\end{array}$ & $\begin{array}{c}\text { 26. } 1.1922 . \\
\text { u } 15 \text { sati }\end{array}$ & $\begin{array}{c}\text { polje } 3 \\
\text { red } 7 \\
\text { broj groba } \\
68\end{array}$ \\
\hline 28 & 38 & $\begin{array}{c}\text { Aleksandar } \\
\text { Starimirović } \\
\text { 3. četa 1. bat. } \\
\text { 5. p. p. }\end{array}$ & $\begin{array}{l}21 \text { god. star } \\
\text { oženjen } \\
\text { Malo Crniće } \\
\text { Požarevac }\end{array}$ & $\begin{array}{l}\text { vojn. } \\
\text { bolnica }\end{array}$ & $\begin{array}{l}\text { Pneumonia } \\
\text { catarhalis } \\
\text { tbc. pulm et } \\
\text { peritonitis }\end{array}$ & $\begin{array}{c}\text { 27. 1. } 1922 . \\
\text { u } 15 \text { sati }\end{array}$ & $\begin{array}{c}\text { polje } 3 \\
\text { red } 7 \\
\text { broj groba } \\
67\end{array}$ \\
\hline 29 & 39 & $\begin{array}{c}\text { Svetozar } \\
\text { Živanović } \\
\text { 3. četa 1. bat. } \\
\text { 36. p. p. } \\
\text { Poljodjelac }\end{array}$ & $\begin{array}{l}21 \text { god. star } \\
\text { oženjen } \\
\text { Lopatanj } \\
\text { Podgorski } \\
\text { Valjevo }\end{array}$ & $\begin{array}{l}\text { vojn. } \\
\text { bolnica }\end{array}$ & $\begin{array}{c}\text { Scarlatina } \\
\text { Pneumonia } \\
\text { catarhalis }\end{array}$ & $\begin{array}{c}28.1 .1922 . \\
\text { u } 15 \text { sati }\end{array}$ & $\begin{array}{c}\text { polje } 3 \\
\text { red } 8 \\
\text { broj groba } \\
36\end{array}$ \\
\hline
\end{tabular}




\begin{tabular}{|c|c|c|c|c|c|c|c|}
\hline 30 & 44 & $\begin{array}{l}\text { Milutin Milo- } \\
\text { šević } \\
\text { 1. bater. } 2 \text {. } \\
\text { diviz. } \\
\text { 14. art. puk. }\end{array}$ & $\begin{array}{l}21 \text { god. star } \\
\text { oženjen } \\
\text { Bratići Župski } \\
\text { Kruševački }\end{array}$ & $\begin{array}{l}\text { vojn. } \\
\text { bolnica }\end{array}$ & $\begin{array}{c}\text { Pneumonia } \\
\text { catarhalis }\end{array}$ & $\begin{array}{c}\text { 31. 1. } 1922 . \\
\text { u } 15 \text { sati }\end{array}$ & \begin{tabular}{|c} 
polje 3 \\
red 8 \\
broj groba \\
35
\end{tabular} \\
\hline 31 & 50 & $\begin{array}{l}\text { Dragutin } \\
\text { Janković } \\
7 . \text { četa } 2 . \\
\text { podosek } \\
\text { granične čete }\end{array}$ & $\begin{array}{l}22 \text { god. star } \\
\text { neoženjen } \\
\text { Osipaonica } \\
\text { Podunavski } \\
\text { Smederevski }\end{array}$ & $\begin{array}{l}\text { vojn. } \\
\text { bolnica }\end{array}$ & $\begin{array}{l}\text { Pneumonia } \\
\text { catarhalis } \\
\text { tbc. }\end{array}$ & $\begin{array}{c}\text { 3. } 2.1922 . \\
\text { u } 15 \text { sati }\end{array}$ & $\begin{array}{c}\text { polje } 3 \\
\text { red } 8 \\
\text { broj groba } \\
34\end{array}$ \\
\hline 32 & 58 & $\begin{array}{l}\text { Aleksandar } \\
\text { Ivanović } \\
\text { 2. četa 1. bat. } \\
\text { 5. p. p. }\end{array}$ & $\begin{array}{c}21 \text { god. star } \\
\text { oženjen } \\
\text { Ličevac Ram- } \\
\text { ski } \\
\text { Požarevac }\end{array}$ & $\begin{array}{l}\text { vojn. } \\
\text { bolnica }\end{array}$ & $\begin{array}{c}\text { Pneumonia } \\
\text { catarhalis }\end{array}$ & $\begin{array}{c}\text { 7. 2. } 1922 . \\
\text { u } 15 \text { sati }\end{array}$ & $\begin{array}{c}\text { polje } 3 \\
\text { red } 8 \\
\text { broj groba } \\
31\end{array}$ \\
\hline 33 & 63 & $\begin{array}{l}\text { Tomo Sević } \\
\text { 1. četa } 1 . \text { bat. } \\
\text { 36. p. p. }\end{array}$ & \begin{tabular}{|c|}
21 god. star \\
neoženjen \\
Gornja Ljubo- \\
vica Azbuko- \\
vački Podrin- \\
ski
\end{tabular} & $\begin{array}{l}\text { vojn. } \\
\text { bolnica }\end{array}$ & $\begin{array}{c}\text { Pneumonia } \\
\text { catarhalis }\end{array}$ & $\begin{array}{c}\text { 9. } 2.1922 . \\
\text { u } 15 \text { sati }\end{array}$ & $\begin{array}{c}\text { polje } 3 \\
\text { red } 8 \\
\text { broj groba } \\
30\end{array}$ \\
\hline 34 & 76 & $\begin{array}{l}\text { Stevan Gvoz- } \\
\text { denović } \\
\text { 3. četa 3. bat. } \\
\text { 36. p. p. }\end{array}$ & $\begin{array}{l}22 \text { god. star } \\
\text { oženjen } \\
\text { Vujetinci } \\
\text { Ljubički } \\
\text { Rudnički }\end{array}$ & $\begin{array}{l}\text { vojn. } \\
\text { bolnica }\end{array}$ & $\begin{array}{c}\text { Pneumonia } \\
\text { catarhalis }\end{array}$ & $\begin{array}{c}\text { 18. 2. } 1922 . \\
\text { u } 15 \text { sati }\end{array}$ & $\begin{array}{c}\text { polje } 3 \\
\text { red } 8 \\
\text { broj groba } \\
74\end{array}$ \\
\hline 35 & 86 & $\begin{array}{l}\text { Arsen Lelić }{ }^{43} \\
\text { 1. čet. 1. bat. } \\
\text { 36. p. p. }\end{array}$ & $\begin{array}{l}21 \text { god. star } \\
\text { Tabanović } \\
\text { Mačvanski } \\
\text { Podrinski }\end{array}$ & $\begin{array}{l}\text { vojn. } \\
\text { bolnica }\end{array}$ & Tbc. pulm. & $\begin{array}{c}\text { 24. 2. } 1922 . \\
\text { u } 15 \text { sati }\end{array}$ & $\begin{array}{c}\text { polje } 3 \\
\text { red } 8 \\
\text { broj groba } \\
73\end{array}$ \\
\hline 36 & 91 & $\begin{array}{c}\text { Dušan Vojvo- } \\
\text { danić } \\
\text { 1. čet. 1. bat. } \\
\text { 36. p. p. }\end{array}$ & $\begin{array}{l}21 \text { god. star } \\
\text { (?) Porečki (?) }\end{array}$ & $\begin{array}{l}\text { vojn. } \\
\text { bolnica }\end{array}$ & $\begin{array}{c}\text { Pneumonia } \\
\text { catarhalis } \\
\text { tbc. pulm. }\end{array}$ & $\begin{array}{c}\text { 1. 3. } 1922 . \\
\text { u } 15 \text { sati }\end{array}$ & \begin{tabular}{|c} 
polje 3 \\
red 8 \\
broj groba \\
72
\end{tabular} \\
\hline 37 & 96 & $\begin{array}{l}\text { Milenko } \\
\text { Kovačević } \\
\text { 1. četa } 1 . \text { bat. } \\
\text { 36. p. p. } \\
\text { poljodjelac }\end{array}$ & $\begin{array}{l}21 \text { god. star } \\
\text { neoženjen } \\
\text { Nevade Ta- } \\
\text { kovski } \\
\text { Rudnički }\end{array}$ & $\begin{array}{l}\text { vojn. } \\
\text { bolnica }\end{array}$ & $\begin{array}{l}\text { Meningitis, } \\
\text { Tbc. }\end{array}$ & $\begin{array}{c}\text { 4. 3. } 1922 . \\
\text { u } 15 \text { sati }\end{array}$ & $\begin{array}{c}\text { polje } 3 \\
\text { red } 8 \\
\text { broj groba } \\
71\end{array}$ \\
\hline 38 & 136 & $\begin{array}{l}\text { Marko Grujić } \\
\text { mitraljeski } \\
\text { odj. 36. p. p. }\end{array}$ & $\begin{array}{l}21 \text { god. star } \\
\text { neoženjen } \\
\text { Bratanić, } \\
\text { Podgorski } \\
\text { Valjevo }\end{array}$ & $\begin{array}{l}\text { vojn. } \\
\text { bolnica }\end{array}$ & Tbc. pulm. & $\begin{array}{c}\text { 24. } 4.1922 . \\
\text { u } 15 \text { sati }\end{array}$ & $\begin{array}{c}\text { polje } 3 \\
\text { red } 9 \\
\text { broj groba } \\
35\end{array}$ \\
\hline 39 & 210 & $\begin{array}{l}\text { Tihomir Mičić } \\
\text { redov } 3 / 3 \text { četa } \\
\text { 36. p. p. }\end{array}$ & $\begin{array}{l}21 \text { god. star } \\
\text { oženjen } \\
\text { Konjuša (?) } \\
\text { Rudnički }\end{array}$ & $\begin{array}{l}\text { vojn. } \\
\text { Bolnica }\end{array}$ & Tbc. pulm. & $\begin{array}{c}\text { 26. 6. } 1922 . \\
\text { u } 15 \text { sati }\end{array}$ & $\begin{array}{c}\text { polje } 3 \\
\text { red } 9 \\
\text { broj groba } \\
33\end{array}$ \\
\hline
\end{tabular}

\footnotetext{
${ }^{43}$ Napomena iz Grobnog očevidnika: „Dne 5. 3. prevezen u Šabac“.
} 
Istorija 20. veka, god. 38, 2/2020, 61-84

\begin{tabular}{|c|c|c|c|c|c|c|c|}
\hline 40 & 221 & $\begin{array}{l}\text { Dragomir } \\
\text { Kuravica } \\
\text { redov 2. esk. } \\
\text { 8. konj. puk } \\
\end{array}$ & $\begin{array}{c}21 \text { god. star } \\
\text { neoženjen (?) } \\
\text { Alibunar } \\
\text { Pančevo }\end{array}$ & $\begin{array}{l}\text { vojn. } \\
\text { bolnica }\end{array}$ & $\begin{array}{l}\text { Pneumonia } \\
\text { catarhalis }\end{array}$ & $\begin{array}{l}\text { 5. } 7.1922 . \\
\text { u } 17 \text { sati }\end{array}$ & $\begin{array}{c}\text { polje } 3 \\
\text { red } 9 \\
\text { broj groba } \\
32 \\
\end{array}$ \\
\hline 41 & 228 & $\begin{array}{c}\text { Milovan Matić } \\
\text { redov granične } \\
\text { trupe }\end{array}$ & $\begin{array}{c}30 \text { god. star } \\
\text { oženjen } \\
\text { Ravno Užički }\end{array}$ & $\begin{array}{l}\text { vojn. } \\
\text { bolnica }\end{array}$ & Tbc. pulm. & $\begin{array}{c}11.7 .1922 . \\
\text { u } 17 \text { sati }\end{array}$ & $\begin{array}{c}\text { polje } 5 \\
\text { red } 19 \\
\text { broj groba } \\
54\end{array}$ \\
\hline 42 & 235 & $\begin{array}{c}\text { Ivan Živković } \\
\text { 2. četa } 1 . \text { bat. } \\
\text { 5. p. p. }\end{array}$ & $\begin{array}{l}21 \text { god. star } \\
\text { neoženjen } \\
\text { Kličevac } \\
\text { Ramski } \\
\text { Požarevac }\end{array}$ & $\begin{array}{l}\text { vojn. } \\
\text { bolnica }\end{array}$ & $\begin{array}{l}\text { Meningitis, } \\
\text { tbc. }\end{array}$ & $\begin{array}{c}\text { 19. } 7.1922 . \\
\text { u } 15 \text { sati }\end{array}$ & $\begin{array}{c}\text { polje } 5 \\
\text { red } 19 \\
\text { broj groba } \\
64\end{array}$ \\
\hline 43 & 332 & $\begin{array}{c}\text { Života Ilić } \\
\text { 3. četa 2. bat. } \\
\text { 36. p. p. }\end{array}$ & $\begin{array}{l}21 \text { god. star } \\
\text { neoženjen } \\
\text { (?) Valjevo }\end{array}$ & $\begin{array}{l}\text { vojn. } \\
\text { bolnica }\end{array}$ & Tbc. pluča & $\begin{array}{c}\text { 11. 11. } 1922 . \\
\text { u } 15 \text { sati }\end{array}$ & $\begin{array}{c}\text { polje } 5 \\
\text { red } 20 \\
\text { broj groba } \\
27\end{array}$ \\
\hline 44 & 66 & $\begin{array}{l}\text { Dragutin } \\
\text { Ivković } \\
\text { 1. četa } 36 . \text { p. } \\
\text { p. }\end{array}$ & $\begin{array}{l}\text { 21. god. star } \\
\text { oženjen } \\
\text { Požarevac }\end{array}$ & $\begin{array}{l}\text { vojn. } \\
\text { bolnica }\end{array}$ & Pneumonia & $\begin{array}{c}\text { 24. 3. } 1923 . \\
\text { u } 16 \text { sati }\end{array}$ & $\begin{array}{c}\text { polje } 5 \\
\text { red } 20 \\
\text { broj groba } \\
70\end{array}$ \\
\hline 45 & 69 & $\begin{array}{l}\text { Josip Kostić } \\
\text { 1. četa } 36 . \\
\text { puk. }\end{array}$ & $\begin{array}{l}\text { 21. god. star } \\
\text { oženjen Lom- } \\
\text { nica (?) Kru- } \\
\text { ševac }\end{array}$ & $\begin{array}{l}\text { vojn. } \\
\text { bolnica }\end{array}$ & Pneumonia & $\begin{array}{c}\text { 27. 3. } 1923 . \\
\text { u } 16 \text { sati }\end{array}$ & $\begin{array}{c}\text { polje } 5 \\
\text { red } 21 \\
\text { broj groba } \\
1\end{array}$ \\
\hline 46 & 70 & $\begin{array}{c}\text { Živan Stojko- } \\
\text { vić } \\
\text { 14. art. puk. }\end{array}$ & $\begin{array}{l}\text { 22. god. star } \\
\text { neoženjen } \\
\text { Kruševac }\end{array}$ & $\begin{array}{l}\text { vojn. } \\
\text { bolnica }\end{array}$ & $\begin{array}{c}\text { ranjen } \\
\text { revolverom } \\
\mathrm{u} \text { trbuh }\end{array}$ & $\begin{array}{c}\text { 27. 3. } 1923 . \\
\text { u } 16 \text { sati }\end{array}$ & $\begin{array}{c}\text { polje } 5 \\
\text { red } 20 \\
\text { broj groba } \\
75\end{array}$ \\
\hline 47 & 77 & $\begin{array}{l}\text { Blagoje Spa- } \\
\text { sojević } \\
\text { 10. četa } 36 . p . \\
\text { p. }\end{array}$ & $\begin{array}{l}\text { 21. god. star } \\
\text { neoženjen } \\
\text { Užice }\end{array}$ & $\begin{array}{l}\text { vojn. } \\
\text { bolnica }\end{array}$ & Pneumonia & $\begin{array}{c}\text { 3. } 4.1923 . \\
\text { u } 16 \text { sati }\end{array}$ & $\begin{array}{c}\text { polje } 5 \\
\text { red } 21 \\
\text { broj groba } \\
9\end{array}$ \\
\hline 48 & 84 & $\begin{array}{c}\text { Dragomir } \\
\text { Popović } \\
\text { 11. četa 36. p. } \\
\text { p. }\end{array}$ & $\begin{array}{l}\text { 22. god. star } \\
\text { neoženjen } \\
\text { Vrnčani Ta- } \\
\text { kovski } \\
\text { Rudnički } \\
\end{array}$ & $\begin{array}{l}\text { vojn. } \\
\text { bolnica }\end{array}$ & Scarlatine & $\begin{array}{c}\text { 9. } 4.1923 . \\
\text { u } 16 \text { sati }\end{array}$ & $\begin{array}{c}\text { polje } 5 \\
\text { red } 21 \\
\text { broj groba } \\
11\end{array}$ \\
\hline 49 & 85 & $\begin{array}{l}\text { Georg Uzum } \\
\text { 3. četa } 36 . \text { p. } \\
\text { p. }\end{array}$ & $\begin{array}{l}\text { 21. god. star } \\
\text { oženjen } \\
\text { (?) Vršac } \\
\text { Pančevo }\end{array}$ & $\begin{array}{l}\text { vojn. } \\
\text { bolnica }\end{array}$ & Scarlatine & $\begin{array}{c}\text { 9. 4. } 1923 . \\
\text { u } 16 \text { sati }\end{array}$ & $\begin{array}{c}\text { polje } 5 \\
\text { red } 21 \\
\text { broj groba } \\
13\end{array}$ \\
\hline 50 & 86 & $\begin{array}{c}\text { Svetomir } \\
\text { Bogičević } \\
\text { 2. četa } 36 . p . \\
\text { p. }\end{array}$ & $\begin{array}{l}\text { 21. god. star } \\
\text { neoženjen } \\
\text { (?) Moravički } \\
\text { Bačanski }\end{array}$ & $\begin{array}{l}\text { vojn. } \\
\text { bolnica }\end{array}$ & Scarlatine & $\begin{array}{c}\text { 10. } 4.1923 . \\
\text { u } 16 \text { sati }\end{array}$ & $\begin{array}{c}\text { polje } 5 \\
\text { red } 21 \\
\text { broj groba } \\
15\end{array}$ \\
\hline 51 & 239 & $\begin{array}{l}\text { Živorad V. } \\
\text { Marković } \\
\text { redov 14. art. } \\
\text { puk. }\end{array}$ & $\begin{array}{c}21 \text { god. star } \\
? \\
\text { Sir(a)kovo }\end{array}$ & $\begin{array}{l}\text { 14. art. } \\
\text { puk. }\end{array}$ & $\begin{array}{c}\text { Ruptura } \\
\text { hebari Szar- } \\
\text { nah (?) }\end{array}$ & $\begin{array}{c}\text { 7. 9. } 1927 . \\
\text { u } 17 \text { sati }\end{array}$ & $\begin{array}{c}\text { polje } 6 \\
\text { red } 24 \\
\text { broj groba } \\
17\end{array}$ \\
\hline
\end{tabular}




\begin{tabular}{|c|c|c|c|c|c|c|c|}
\hline 52 & 96 & $\begin{array}{l}\text { Milovan } \\
\text { Anđić } \\
\text { vojnik }\end{array}$ & $\begin{array}{l}22 \text { god. star } \\
\text { neoženjen } \\
\text { (?) Podrinski }\end{array}$ & $\begin{array}{l}\text { vojn. } \\
\text { bolnica }\end{array}$ & $\begin{array}{l}\text { Broncho } \\
\text { pneumonia }\end{array}$ & $\begin{array}{c}\text { 29. 3. } 1928 . \\
\text { u } 10 \text { sati }\end{array}$ & $\begin{array}{c}\text { polje } 6 \\
\text { red } 25 \\
\text { broj groba } \\
25\end{array}$ \\
\hline 53 & 98 & $\begin{array}{l}\text { Vasilije Simić } \\
\text { redov pješ. } 2 \text {. } \\
\text { čet. 36. p. p. } \\
\text { „Jelačića“" }\end{array}$ & $\begin{array}{l}23 \text { god. star } \\
\text { oženjen } \\
\text { Metković } \\
\text { Šabac }\end{array}$ & bolnica & $\begin{array}{l}\text { Peritonitis } \\
\text { diffusa }\end{array}$ & $\begin{array}{l}\text { 2. } 4.1928 \text {. } \\
\text { u } 161 / 2 \text { sati }\end{array}$ & $\begin{array}{c}\text { polje } 6 \\
\text { red } 25 \\
\text { broj groba } \\
27\end{array}$ \\
\hline 54 & 136 & $\begin{array}{c}\text { Milosav S. } \\
\text { Simonović44 } \\
\text { vojnik (zem- } \\
\text { ljoradnik) }\end{array}$ & $\begin{array}{c}22 \text { god. star } \\
\text { oženjen } \\
\text { Crljenac } \\
\text { Resavski } \\
\text { Požarevac }\end{array}$ & $\begin{array}{l}\text { vojn. } \\
\text { bolnica }\end{array}$ & $\begin{array}{l}\text { Pleuropne- } \\
\text { umonia tbc. } \\
\text { chyrcarditis }\end{array}$ & $\begin{array}{c}\text { 22. 5. } 1929 . \\
\text { u } 15 \text { sati }\end{array}$ & $\begin{array}{c}\text { polje } 7 \\
\text { red } 20 \\
\text { broj groba } \\
19\end{array}$ \\
\hline 55 & 224 & $\begin{array}{l}\text { Miloš Jovičić } \\
\text { redov 10. čete } \\
\text { 36. p. p. Jela- } \\
\text { čić }\end{array}$ & $\begin{array}{l}22 \text { god. star } \\
\text { neoženjen } \\
\text { (?) Petrovac } \\
\text { Vrbaska }\end{array}$ & $\begin{array}{l}\text { vojn. } \\
\text { bolnica }\end{array}$ & $\begin{array}{l}\text { zapaljenje } \\
\text { pluća }\end{array}$ & $\begin{array}{l}2.10 .1930 . \\
\text { prije podne }\end{array}$ & $\begin{array}{c}\text { polje } 7 \\
\text { red } 23 \\
\text { broj groba } \\
23\end{array}$ \\
\hline 56 & 234 & $\begin{array}{l}\text { Ljubomir } \\
\text { Milovanović } \\
\text { redov } 36 . \mathrm{p} . \\
\text { puka }\end{array}$ & $\begin{array}{c}21 \text { god. star } \\
\text { neoženjen } \\
\text { Zagoni Bjelina }\end{array}$ & bolnica & $\begin{array}{c}\text { Vulnus } \\
\text { sclopetarium } \\
\text { thoracis lat- } \\
\text { d. }\end{array}$ & $\begin{array}{c}\text { 21. } 10.1930 . \\
\text { u } 8 \text { sati }\end{array}$ & $\begin{array}{c}\text { polje } 7 \\
\text { red } 23 \\
\text { broj groba } \\
34\end{array}$ \\
\hline 57 & 110 & $\begin{array}{l}\text { Uroš Tomaše- } \\
\text { vić } \\
\text { redov mitralj. } \\
\text { čete } \\
\text { 36. p. puka }\end{array}$ & $\begin{array}{l}22 \text { god. star } \\
\text { neoženjen } \\
\text { Bregovi (?) }\end{array}$ & vojn. boln. & $\begin{array}{l}\text { Paralysis } \\
\text { cordis }\end{array}$ & $\begin{array}{c}\text { 17. 4. } 1931 . \\
\text { u } 15 \text { sati }\end{array}$ & $\begin{array}{c}\text { polje } 7 \\
\text { red } 24 \\
\text { broj groba } \\
74\end{array}$ \\
\hline 58 & 129 & $\begin{array}{l}\text { Branko M. } \\
\text { Uks } \\
\text { redov } 12 \text {. čete } \\
\text { 3. bat. } \\
\text { 36. p. p. }\end{array}$ & $\begin{array}{l}22 \text { god. star } \\
\text { oženjen Lju- } \\
\text { toglava } \\
\text { Šar planina } \\
\text { Vrbas }\end{array}$ & vojn. boln. & $\begin{array}{l}\text { abcesus } \\
\text { cerebri }\end{array}$ & $\begin{array}{c}\text { 30. 4. } 1931 . \\
\text { u } 15 \text { sati }\end{array}$ & $\begin{array}{c}\text { polje } 7 \\
\text { red } 25 \\
\text { broj groba } \\
15\end{array}$ \\
\hline 59 & 202 & $\begin{array}{l}\text { Jordan Laza- } \\
\text { rević } \\
\text { redov } 7 . \text { četa } \\
\text { 36. p. p. }\end{array}$ & $\begin{array}{l}21 \text { god. star } \\
\text { neoženjen } \\
\text { Rakovice (?) } \\
\text { Palanački }\end{array}$ & vojn. boln. & $\begin{array}{l}\text { zapaljenje } \\
\text { pluča }\end{array}$ & $\begin{array}{c}\text { 27. 7. } 1931 . \\
\text { u } 15 \text { sati }\end{array}$ & $\begin{array}{c}\text { polje } 7 \\
\text { red } 25 \\
\text { broj groba } \\
52\end{array}$ \\
\hline 60 & 210 & $\begin{array}{l}\text { Božidar S. } \\
\text { Trajković } \\
\text { redov 36. p. p. }\end{array}$ & $\begin{array}{c}22 \text { god. star } \\
\text { udovac iza } \\
\text { Stojanke } \\
\text { Krševica } \\
\text { Klinovac }\end{array}$ & bolnica & $\begin{array}{l}\text { Pneumonia } \\
\text { crouposa } \\
\text { Empyema } \\
\text { Thoracis }\end{array}$ & $\begin{array}{l}\text { 4. } 8.1931 . \\
\text { u } 15 \text { sati }\end{array}$ & $\begin{array}{c}\text { polje } 7 \\
\text { red } 25 \\
\text { broj groba } \\
56\end{array}$ \\
\hline 61 & 234 & $\begin{array}{l}\text { Miroslav D. } \\
\text { Jovanović } \\
\text { redov 7. č. } 2 . \\
\text { b. } 36 . \text { p. p. }\end{array}$ & $\begin{array}{l}22 \text { god. star } \\
\text { neoženjen } \\
\text { Naupare } \\
\text { Moravska }\end{array}$ & $\begin{array}{l}\text { vojn. } \\
\text { bolnica }\end{array}$ & otok pluča & $\begin{array}{c}\text { 1. } 9.1931 . \\
\text { u } 15 \text { sati }\end{array}$ & $\begin{array}{c}\text { polje } 7 \\
\text { red } 25 \\
\text { broj groba } \\
72\end{array}$ \\
\hline
\end{tabular}

\footnotetext{
${ }^{44}$ Napomena iz Grobnog očevidnika: „25. 5. 1929. ekshumiran i prevežen u zavičaj“.
} 
Istorija 20. veka, god. 38, 2/2020, 61-84

\begin{tabular}{|c|c|c|c|c|c|c|c|}
\hline 62 & 274 & $\begin{array}{l}\text { Slavko N. } \\
\text { Šušić } \\
\text { redov 8. čete } \\
\text { 36. p. p. }\end{array}$ & $\begin{array}{l}21 \text { god. star } \\
\text { neoženjen } \\
\text { Progoreoci } \\
\text { srez Žički } \\
\text { Moravska }\end{array}$ & $\begin{array}{l}\text { vojn. } \\
\text { bolnica }\end{array}$ & $\begin{array}{c}\text { Colitis } \\
\text { acutis } \\
\text { (dysenteria) }\end{array}$ & $\begin{array}{c}\text { 19. 10. } 1931 . \\
\text { u } 15 \text { sati }\end{array}$ & \begin{tabular}{|c} 
polje 8 \\
red 15 \\
broj groba \\
1
\end{tabular} \\
\hline 63 & 89 & $\begin{array}{l}\text { Ljubomir S. } \\
\text { Stojanović } \\
\text { redov 1. bat. } \\
\text { 2. div. } \\
\text { 14. art. puk. }\end{array}$ & $\begin{array}{l}21 \text { god. star } \\
\text { neoženjen } \\
\text { selo Mezgraja } \\
\text { Babušnica } \\
\text { Moravska }\end{array}$ & vojn. boln. & $\begin{array}{l}\text { Meningitis } \\
\text { cerebrospin. }\end{array}$ & $\begin{array}{c}\text { 14. } 4.1933 . \\
\text { u } 15 \text { sati }\end{array}$ & $\begin{array}{c}\text { polje } 8 \\
\text { red } 15 \\
\text { broj groba } \\
4\end{array}$ \\
\hline 64 & 120 & $\begin{array}{l}\text { Božidar Sla- } \\
\text { menković } \\
\text { redov 1. mitra- } \\
\text { ljez. čete } \\
\text { 36. p. p. }\end{array}$ & $\begin{array}{l}23 \text { god. star } \\
\text { oženjen sa } \\
\text { Zorkom } \\
\text { Miroševac } \\
\text { Leskovački } \\
\text { Vardarska }\end{array}$ & bolnica & $\begin{array}{c}\text { Pleuritis } \\
\text { dextri sepsis }\end{array}$ & $\begin{array}{c}\text { 3. } 6.1933 . \\
\text { u } 8 \text { sati }\end{array}$ & $\begin{array}{c}\text { polje } 8 \\
\text { red } 15 \\
\text { broj groba } \\
5\end{array}$ \\
\hline 65 & 192 & $\begin{array}{c}\text { Mladen A. } \\
\text { Ćosić } \\
\text { redov 2. čete } 1 . \\
\text { bat., 36. p. p. }\end{array}$ & $\begin{array}{c}21 \text { god. star } \\
\text { oženjen } \\
\text { Bioska Užice } \\
\text { Drinska }\end{array}$ & $\begin{array}{l}\text { vojn. } \\
\text { bolnica }\end{array}$ & $\begin{array}{l}\text { Pneumonia } \\
\text { crouposa }\end{array}$ & $\begin{array}{c}\text { 23. 9. } 1933 . \\
\text { u } 15 \text { sati }\end{array}$ & $\begin{array}{c}\text { polje } 8 \\
\text { red } 15 \\
\text { broj groba } \\
6\end{array}$ \\
\hline 66 & 259 & $\begin{array}{l}\text { Lazar M. } \\
\text { Moglov } \\
\text { redov 8. bat. } \\
\text { 1. div. } \\
\text { 14. art. puk. }\end{array}$ & $\begin{array}{l}22 \text { god. star } \\
\text { neoženjen } \\
\text { Javorani } \\
\text { Kotor Varoš }\end{array}$ & $\begin{array}{l}\text { vojn. } \\
\text { bolnica }\end{array}$ & $?$ & $\begin{array}{c}\text { 14. } 12.1933 . \\
\text { u } 15 \text { sati }\end{array}$ & $\begin{array}{c}\text { polje } 8 \\
\text { red } 15 \\
\text { broj groba } \\
7\end{array}$ \\
\hline 67 & 57 & $\begin{array}{c}\text { Milan B. } \\
\text { Jeremić } \\
\text { kaplar 10. čete } \\
\text { 36. p. p. }\end{array}$ & $\begin{array}{l}27 \text { god. star } \\
\text { oženjen } \\
\text { Lugavčina } \\
\text { Podunavski } \\
\text { Dunavski }\end{array}$ & $\begin{array}{l}\text { vojn. } \\
\text { bolnica }\end{array}$ & Gripp & $\begin{array}{c}\text { 25. 2. } 1935 . \\
\text { u } 15 \text { sati }\end{array}$ & $\begin{array}{c}\text { polje } 8 \\
\text { red } 15 \\
\text { broj groba } \\
8\end{array}$ \\
\hline 68 & 145 & $\begin{array}{l}\text { Jelenko Sibi- } \\
\text { nović } \\
\text { redov regrut }\end{array}$ & $\begin{array}{l}23 \text { god. star } \\
\text { oženjen sa } \\
\text { Ružom } \\
\text { Nikolinac } \\
\text { Soko Banja }\end{array}$ & bolnica & $\begin{array}{l}\text { Insuficientia } \\
\text { cordis }\end{array}$ & $\begin{array}{c}\text { 22. 5. } 1935 . \\
\text { u } 8 \text { sati }\end{array}$ & $\begin{array}{c}\text { polje } 8 \\
\text { red } 15 \\
\text { broj groba } \\
9\end{array}$ \\
\hline 69 & 182 & $\begin{array}{l}\text { Marijan Djor- } \\
\text { djević } \\
\text { redov 9. čete } \\
\text { 3. bat. } \\
\text { 36. p. p. }\end{array}$ & $\begin{array}{l}24 \text { god. star } \\
\text { oženjen (?) } \\
\text { Jablanački } \\
\text { Vardarska }\end{array}$ & $\begin{array}{l}\text { vojn. } \\
\text { bolnica }\end{array}$ & $\begin{array}{l}\text { Pneumonia } \\
\text { crouposa }\end{array}$ & $\begin{array}{c}\text { 1. } 7.1935 . \\
\text { u } 15 \text { sati }\end{array}$ & $\begin{array}{c}\text { polje } 8 \\
\text { red } 15 \\
\text { broj groba } \\
10\end{array}$ \\
\hline 70 & 202 & $\begin{array}{l}\text { Živko D. } \\
\text { Simićc5 } \\
\text { vojnik }\end{array}$ & $\begin{array}{c}23 \text { god. star } \\
\text { oženjen } \\
\text { Mali Požare- } \\
\text { vac }\end{array}$ & $\begin{array}{l}\text { vojn. } \\
\text { bolnica }\end{array}$ & $\begin{array}{l}\text { Meningitis } \\
\text { cerebro } \\
\text { spinalis } \\
\text { epidemosa }\end{array}$ & $\begin{array}{c}\text { 26. } 7.1935 . \\
\text { u } 16 \text { sati }\end{array}$ & $\begin{array}{c}\text { polje } 8 \\
\text { red } 15 \\
\text { broj groba } \\
11\end{array}$ \\
\hline 71 & 203 & $\begin{array}{l}\text { Svetislav } \\
\text { Dojčinović } \\
\text { vojnik }\end{array}$ & $\begin{array}{l}22 \text { god. star } \\
\text { oženjen } \\
\text { Bučumet }\end{array}$ & $\begin{array}{l}\text { vojn. } \\
\text { bolnica }\end{array}$ & $\begin{array}{l}\text { Gangrena } \\
\text { pulmon. } \\
\text { dex. et } \\
\text { pneumonia } \\
\text { cetter. }\end{array}$ & $\begin{array}{c}\text { 27. } 7.1935 . \\
\text { u } 15 \text { sati }\end{array}$ & $\begin{array}{c}\text { polje } 8 \\
\text { red } 15 \\
\text { broj groba } \\
12\end{array}$ \\
\hline
\end{tabular}

${ }^{45}$ Napomena iz Grobnog očevidnika: „Dne 21. 8. 1935. prevežen u Beograd“. 


\begin{tabular}{|c|c|c|c|c|c|c|c|}
\hline 72 & 36 & $\begin{array}{l}\text { Đorđe V. } \\
\text { Mičeta } \\
\text { redov 5. čete } \\
\text { 53. p. p. }\end{array}$ & $\begin{array}{l}23 \text { god. star } \\
\text { neoženjen } \\
\text { (?) Vučitrnski } \\
\text { Moravska }\end{array}$ & $\begin{array}{l}\text { vojn. } \\
\text { bolnica }\end{array}$ & $\begin{array}{c}\text { Prelom } \\
\text { lubanje } \\
\text { potres moz- } \\
\mathrm{ga}\end{array}$ & $\begin{array}{c}\text { 13. 2. } 1937 . \\
\text { u } 15 \text { sati }\end{array}$ & $\begin{array}{c}\text { polje } 8 \\
\text { red } 15 \\
\text { broj groba } \\
34\end{array}$ \\
\hline 73 & 72 & $\begin{array}{l}\text { Ljubomir P. } \\
\text { Lekić } \\
\text { redov } 8 \text {. čete } \\
\text { 36. p. p. }\end{array}$ & $\begin{array}{l}28 \text { god. star } \\
\text { oženjen } \\
\text { Sovljak } \\
\text { Tamnavski }\end{array}$ & $\begin{array}{l}\text { vojn. } \\
\text { bolnica }\end{array}$ & Tbc. Mil. & $\begin{array}{c}\text { 29. 3. } 1937 . \\
\text { u } 14 \text { sati }\end{array}$ & $\begin{array}{c}\text { polje } 8 \\
\text { red } 15 \\
\text { broj groba } \\
35\end{array}$ \\
\hline 74 & 83 & $\begin{array}{l}\text { Slavko Milo- } \\
\text { vanović } \\
\text { redov regrut } 4 . \\
\text { čet. } \\
\text { 33. peš. puk. }\end{array}$ & $\begin{array}{c}23 \text { god. star } \\
\text { neoženjen } \\
\text { Latvica Arilj- } \\
\text { ski } \\
\text { Drinska }\end{array}$ & $\begin{array}{l}\text { vojn. } \\
\text { bolnica }\end{array}$ & $\begin{array}{c}\text { Insuficientia } \\
\text { cordis Em- } \\
\text { phyema } \\
\text { thoracis }\end{array}$ & $\begin{array}{c}\text { 15. 4. } 1937 . \\
\text { u } 16 \text { sati }\end{array}$ & $\begin{array}{c}\text { polje } 8 \\
\text { red } 15 \\
\text { broj groba } \\
36\end{array}$ \\
\hline 75 & 108 & $\begin{array}{l}\text { Jordan D. } \\
\text { Jačimović } \\
\text { redov 1. čete } \\
\text { 36. p. p. Jela- } \\
\text { čić }\end{array}$ & $\begin{array}{l}22 \text { god. star } \\
\text { oženjen } \\
\text { Gradac Pala- } \\
\text { nački } \\
\text { Vardarska }\end{array}$ & $\begin{array}{l}\text { vojna } \\
\text { bolnica }\end{array}$ & $\begin{array}{l}\text { zapaljenje } \\
\text { pluča }\end{array}$ & $\begin{array}{c}\text { 22. 4. } 1938 . \\
\text { u } 15 \text { sati }\end{array}$ & $\begin{array}{c}\text { polje } 8 \\
\text { red } 15 \\
\text { broj groba } \\
39\end{array}$ \\
\hline 76 & 112 & $\begin{array}{c}\text { Jakov M. } \\
\text { Vučić } \\
\text { redov rekrut } 3 . \\
\text { ćete } \\
\begin{array}{c}\text { 36. p. p. Jela- } \\
\text { čić }\end{array}\end{array}$ & $\begin{array}{l}25 \text { god. star } \\
\text { oženjen } \\
\text { Mačkovac } \\
\text { Rasinski } \\
\text { Moravska }\end{array}$ & $\begin{array}{l}\text { vojna } \\
\text { bolnica }\end{array}$ & $\begin{array}{l}\text { zapaljenje } \\
\text { pluča }\end{array}$ & $\begin{array}{c}\text { 26. } 4.1938 . \\
\text { u } 15 \text { sati }\end{array}$ & $\begin{array}{c}\text { polje } 8 \\
\text { red } 15 \\
\text { broj groba } \\
40\end{array}$ \\
\hline 77 & 115 & \begin{tabular}{|l} 
Petar F. Stoj- \\
ković \\
redov regrut 2. \\
mitraljeske \\
čete 36. p. p. \\
Jelačića \\
\end{tabular} & $\begin{array}{l}26 \text { god. star } \\
\text { neoženjen } \\
\text { Vitina Gnji- } \\
\text { lanski Vardar- } \\
\text { ska }\end{array}$ & $\begin{array}{l}\text { vojna } \\
\text { bolnica }\end{array}$ & $\begin{array}{l}\text { zapaljenje } \\
\text { pluča }\end{array}$ & $\begin{array}{c}\text { 28. 4. } 1938 . \\
\text { u } 15 \text { sati }\end{array}$ & $\begin{array}{c}\text { polje } 8 \\
\text { red } 15 \\
\text { broj groba } \\
41\end{array}$ \\
\hline 78 & 207 & $\begin{array}{c}\text { Radmilo } \\
\text { Cvetković } \\
\text { vojnik regrut }\end{array}$ & $\begin{array}{l}21 \text { god. star } \\
\text { oženjen } \\
\text { Sagonjevo } \\
\text { Žučka }\end{array}$ & bolnica & $\begin{array}{c}\text { Peritonitis } \\
\text { diffusa? } \\
\text { Ruptura? } \\
\text { Paralysis } \\
\text { cordis }\end{array}$ & $\begin{array}{c}\text { 30. 8. } 1938 . \\
\text { u } 15 \text { sati }\end{array}$ & $\begin{array}{c}\text { polje (?) } \\
\text { red (?) } \\
\text { broj groba } \\
\text { (?) }\end{array}$ \\
\hline 79 & 188 & $\begin{array}{c}\text { Dušan Simu- } \\
\text { nović } \\
\text { redov obvez- } \\
\text { nik } 1 \text {. čete } 21 \text {. } \\
\text { radnički bata- } \\
\text { ljun }\end{array}$ & $\begin{array}{l}30 \text { god. star } \\
\text { oženjen (?) } \\
\text { Tetovski } \\
\text { Vardarska }\end{array}$ & $\begin{array}{l}\text { vojna } \\
\text { bolnica }\end{array}$ & $\begin{array}{c}\text { utopio se } \\
\text { nenamjerno }\end{array}$ & $\begin{array}{l}\text { 7. } 7.1940 . \\
\text { u } 10 \text { sati }\end{array}$ & $\begin{array}{c}\text { polje } 8 \\
\text { red } 16 \\
\text { broj groba } \\
5\end{array}$ \\
\hline 80 & 273 & $\begin{array}{c}\text { Dušan M. } \\
\text { Stojković } \\
\text { redov regrut } 8 . \\
\text { baterijske } \\
\text { 14. art. puka }\end{array}$ & $\begin{array}{l}21 \text { god. star } \\
\text { neoženjen } \\
\text { Ponor srez } \\
\text { Poljanički }\end{array}$ & $\begin{array}{l}\text { vojna } \\
\text { bolnica }\end{array}$ & $\begin{array}{l}\text { Meningitis } \\
\text { tbc. }\end{array}$ & $\begin{array}{c}\text { 11. 10. } 1940 . \\
\text { u } 15 \text { sati }\end{array}$ & $\begin{array}{c}\text { polje } 8 \\
\text { red } 16 \\
\text { broj groba } \\
8\end{array}$ \\
\hline
\end{tabular}


Istorija 20. veka, god. 38, 2/2020, 61-84

\begin{tabular}{|c|c|c|c|c|c|c|c|}
\hline 81 & 27 & $\begin{array}{l}\text { Milorad Spa- } \\
\text { sić } \\
\text { redov pješak }\end{array}$ & $\begin{array}{l}21 \text { god. star } \\
\text { oženjen sa } \\
\text { Budinka } \\
\text { Grdelica srez } \\
\text { Vlasotinački } \\
\text { Moravska }\end{array}$ & bolnica & $\begin{array}{l}\text { Appendictis } \\
\text { ac. Perfora- } \\
\text { tio gangrae- } \\
\text { na peritoni- } \\
\text { tis diffusa }\end{array}$ & $\begin{array}{c}25.1 .1941 . \\
\text { u } 9 \text { sati }\end{array}$ & \begin{tabular}{|c} 
polje 8 \\
red 16 \\
broj groba \\
9
\end{tabular} \\
\hline 82 & 102 & $\begin{array}{l}\text { Vladimir } \\
\text { Simić } \\
\text { redov 1. eska- } \\
\text { dron } \\
\text { 8. konjički } \\
\text { puk } \\
\text { „K. Andrej“, } \\
\text { Čakovec }\end{array}$ & $\begin{array}{l}23 \text { god. star } \\
\text { oženjen? } \\
\text { (?) srez Jase- } \\
\text { nički } \\
\text { Dunavska }\end{array}$ & bolnica & $\begin{array}{l}\text { Vulnera } \\
\text { torz, facei } \\
\text { (?) }\end{array}$ & $\begin{array}{c}\text { 16. } 4.1941 . \\
\text { u } 15 \text { sati }\end{array}$ & $\begin{array}{c}\text { polje } 8 \\
\text { red } 16 \\
\text { broj groba } \\
11\end{array}$ \\
\hline
\end{tabular}

\section{REFERENCE}

- Bjelajac, Mile. Vojska Kraljevine Srba, Hrvata i Slovenaca 1918-1921. Beograd: Narodna knjiga, Institut za istoriju radničkog pokreta Srbije, 1988.

- Bogdanović, Lazar. Srpska pravoslavna crkva sv. Đurđa u Varaždinu. Sremski Karlovci: Srpska manastirska štamparija, 1897.

- Damjanović, Dragan. „Gradnja i opremanje varaždinske pravoslavne crkve 1884. godine“. Radovi Zavoda za znanstveni rad Varaždin, 24, (2013), 317-340.

- Huzjan, Vladimir. „Raspuštanje Hrvatskog domobranstva nakon završetka Prvog svjetskog rata“. Casopis za suvremenu povijest, 37, (2005), 445-465.

- Huzjan, Vladimir. „O primjerima projugoslavenski orijentirane varaždinske gradske uprave prema kralju Aleksandru I. Karađorđeviću“. Radovi Zavoda za znanstveni rad Varaždin, 21, (2010), 219-252.

- Huzjan, Vladimir. „Varaždin u vrijeme Države Slovenaca, Hrvata i Srba - od 29. listopada do 1. prosinca 1918. godine“. Radovi Zavoda za znanstveni rad Varaždin, 22, (2011), 249-281.

- Huzjan, Vladimir. „Varaždin u zadnjim mjesecima Kraljevine Jugoslavije i prvim Nezavisne Države Hrvatske“. Radovi Zavoda za znanstveni rad Varaž$\operatorname{din}, 23,(2012), 363-400$.

- Huzjan, Vladimir. „Život generala Kraljevine Jugoslavije u Hrvatskoj - Panta Draškić u Varaždinu“. Historia Varasdiensis. Časopis za varaždinsku povjesnicu, 2, (2012), 175-184.

- Huzjan, Vladimir. Varaždin i vojska u međuratnom razdoblju (1918.-1941.). Zagreb-Varaždin: Hrvatska akademija znanosti i umjetnosti, Zavod za znanstveni rad u Varaždinu, 2017.

- Huzjan, Vladimir. „Expropriation of feudal property in the interwar period examples of free and royal town of Varaždin and Stari grad seniorate possession belonging to counts of Erdödy“. Review of Croatian History, XV, 1, (2019), 151-164. https://doi.org/10.22586/review.v15i1.9745

- Jelić-Butić, Fikreta. „Iz povijesti četničkog pokreta u Hrvatskoj između dva rata (1934.-1936.). Prilog građi o četničkim udruženjima u Savskoj banovini 
1934.-1936.“, Radovi Zavoda za hrvatsku povijest Filozofskog fakulteta, 21, (1988), 209.

- Karakaš Obradov, Marica. „Migracije srpskog stanovništva na području Nezavisne Države Hrvatske tijekom 1941. godine“, Časopis za suvremenu povijest, 3, (2011), 801-826.

- Kralj i narod. Trijumfalna putovanja Njegova Veličanstva Kralja po Savskoj banovini 1. VI.-18. VI. 1931. Ur. Petar Mihočević. Zagreb, 1931.

- Krivošić, Stjepan. Stanovništvo i demografske prilike u sjeverozapadnoj Hrvatskoj u 18. i prvoj polovini 19. stoljeća. Zagreb-Varaždin: Zavod za znanstveni rad HAZU u Varaždinu, 1991.

- Nikolić, Jovan. Aktivnost Utješenovića u životu pravoslavne parohije i crkvene opštine u Varaždinu s posebnim osvrtom na gradnju hrama sv. Đurđa. Zagreb: 1990.

- Petrić, Hrvoje. „Iz najstarije povijesti Srba u Podravini“. Podravina: časopis za multidisciplinarna istraživanja, 30, (2016), 199-212.

- Petrić Hrvoje, i Filip Škiljan. Iz povijesti Srba u Varaždinskoj županiji od prvih doseljavanja do današnjih dana. Zagreb: Grafocentar, 2017.

- Šadek, Vladimir. „Postupanje ustaškog režima s imovinom Židova i Srba u kotarima Koprivnica i Đurđevac (1941.-1942.)“, Podravina: časopis za multidisciplinarna istraživanja, 28, (2015), 5-16.

- Škiljan, Filip. Organizirana prisilna iseljavanja Srba iz NDH. Zagreb: Srpsko narodno vijeće, 2014. 
VLADIMIR HUZJAN, PhD, Senior Research Fellow

Institute for Scientific Work of the Croatian Academy of Sciences and Arts in Varaždin

Varaždin, Republic of Croatia

vhuzjan@gmail.com

\section{ABOUT INTERRED SERBIAN SOLDIERS IN VARAŽDIN CEMETERY BETWEEN TWO WORLD WARS}

\section{Summary}

In this paper, the author writes about interred Serbian soldiers in the Varaždin cemetery between World War I and World War II. The data was taken from the archival books The Graveyard Records (1919-1939) and The Graveyard Records (1940-1949) kept by the municipal company Parkovi. The processed data relates to Serb soldiers born on the territory of the Kingdom of Serbs, Croats, and Slovenes and were in military service in Varaždin, where they died and were buried in a local cemetery.

In the period between the two world wars, soldiers in Varaždin were serving in one of the city's barracks. Of the total number of 208 deceased soldiers, 82 were Serbs. Thanks to the information in the archival books, we know their identity - name, surname, age, marital status, place of birth, and the illness from which they died. The majority of the dead soldiers, 62 percent were recruits and only one was an officer - a 78-year-old veteran of the AustroHungarian Army. Most of the interred soldiers died at the age of 21 or 22 and served mainly in the 36th Jelačić Infantry Regiment in Varaždin.

Almost all the soldiers died in the local military hospital or in the city hospital. As for their origin, most of them (11) were born in Požarevac, five in Valjevo, four each in Gnjilane, Kruševac, Smederevo, and Užice, three in Takovo, and one or two soldiers in the other mentioned places. They died mostly from lung disease (54 percent), heart disease and gunshot wounds (seven percent), scarlet fever and meningitis (five percent), and drowning (four percent). Other diseases were recorded in a small percentage or occurred once, such as influenza, gangrene, or dysentery.

In the end it should be noted that today no graves or external features suggest that soldiers of the Kingdom of SHS/Yugoslavia were buried at the Varaždin city cemetery.

KEYWORDS: Varaždin, Army, Serbian Soldiers, Graveyard, Disease, Death, Yugoslavia, Kingdom of SCS 